Foss. Rec., 21, 183-205, 2018

https://doi.org/10.5194/fr-21-183-2018

(C) Author(s) 2018. This work is distributed under

the Creative Commons Attribution 4.0 License.

\title{
The Paleocene record of marine diatoms in deep-sea sediments
}

\author{
Johan Renaudie $^{1}$, Effi-Laura Drews ${ }^{1,2}$, and Simon Böhne ${ }^{1,2}$ \\ ${ }^{1}$ Museum für Naturkunde, Leibniz-Institut für Evolutions- und Biodiversitätsforschung, Berlin, Germany \\ ${ }^{2}$ Rheinische Friedrich-Wilhelms-Universität, Bonn, Germany
}

Correspondence: Johan Renaudie (johan.renaudie@mfn.berlin)

Received: 27 March 2018 - Revised: 5 August 2018 - Accepted: 8 August 2018 - Published: 20 August 2018

\begin{abstract}
Marine planktonic diatoms, as today's ocean main carbon and silicon exporters, are central to developing an understanding of the interplay between the evolution of marine life and climate change. The diatom fossil record extends as far as the Early Cretaceous, and the late Paleogene to Recent interval is relatively complete and well documented. Their early Paleogene record, when diatoms first expanded substantially in the marine plankton, is hampered by decreased preservation (notably an episode of intense chertification in the early Eocene) as well as by observation bias. In this article, we attempt to correct for the latter by collecting diatom data in various Paleocene samples from legacy Deep Sea Drilling Project and Ocean Drilling Program deep-sea sediment sections. The results show a different picture from what previous analyses concluded, in that the Paleocene deep-sea diatoms seem in fact to have been as diverse and abundant as in the later Eocene, while exhibiting very substantial survivorship of Cretaceous species up until the Eocene.
\end{abstract}

\section{Introduction}

Diatoms are known from the fossil record as early as in the Early Cretaceous (Harwood et al., 2004, 2007), although molecular phylogenies tend to place their origin sometime between the Permian and the early Jurassic (Sorhannus, 2007; Medlin, 2015). They supposedly originated from freshwater forms (Medlin, 2002; Harwood et al., 2004, 2007; Medlin, 2016) and invaded the oceans first with benthic and littoral forms in the earliest part of the Cretaceous and then with properly pelagic forms at the end of the Early Cretaceous, which began radiation in the Late Cretaceous (Harwood and Nikolaev, 1995; Harwood et al., 2007). From that point, they are currently thought to have slowly diversified continuously through the later Cretaceous and the Cenozoic, with two pulses of increased diversification: a short-term one near the Eocene-Oligocene transition (Rabosky and Sorhannus, 2009; Lazarus et al., 2014; Cermeño et al., 2015) and a second, larger one after the beginning of the Miocene (Lazarus et al., 2014; Cermeño et al., 2015).

Despite initial colonization of the open ocean in the earlier Late Cretaceous (Harwood and Nikolaev, 1995; Harwood et al., 2007), they are, in the literature, only found in this setting worldwide, consistently well preserved and in significant amounts, only at the end of the middle Eocene (e.g. Baldauf and Barron, 1990; Barron et al., 2015; Renaudie, 2016). Paleocene diatoms, in particular, are understudied. While diatom-bearing land sections are known from this time period (Harwood, 1988; Homann, 1991; Fenner, 1994; Hollis et al., 2017), in particular on the Russian platform (e.g. Jousé, 1949, 1955; Oreshkina and Aleksandrova, 2007; Aleksandrova et al., 2012; Radionova et al., 2003; Oreshkina and Radionova, 2014), then an epicontinental shallow sea, few diatom-bearing Paleocene sediments have been retrieved or studied from the deep sea (Mukhina, 1976; Gombos Jr., 1977, 1984; Fenner, 1991, 2015; Fourtanier, 1991).

This scarcity of Paleocene data seriously hinders our ability to reliably reconstruct the early Cenozoic macroevolutionary history of marine planktonic diatoms (Cervato and Burckle, 2003; Lazarus et al., 2014; Renaudie, 2016) and with it our ability to understand the relation between their evolution, the evolution of other planktonic forms and the evolution of climate and the oceans. In this paper, we attempt to fill that gap in our knowledge by exploring various Paleocene Deep Sea Drilling Project (DSDP) and Ocean Drilling Program (ODP) sites in order to get a better sense of how this group became one of the ocean's main carbon (Smetacek, 1999) and silica sinks (Tréguer et al., 1995). 


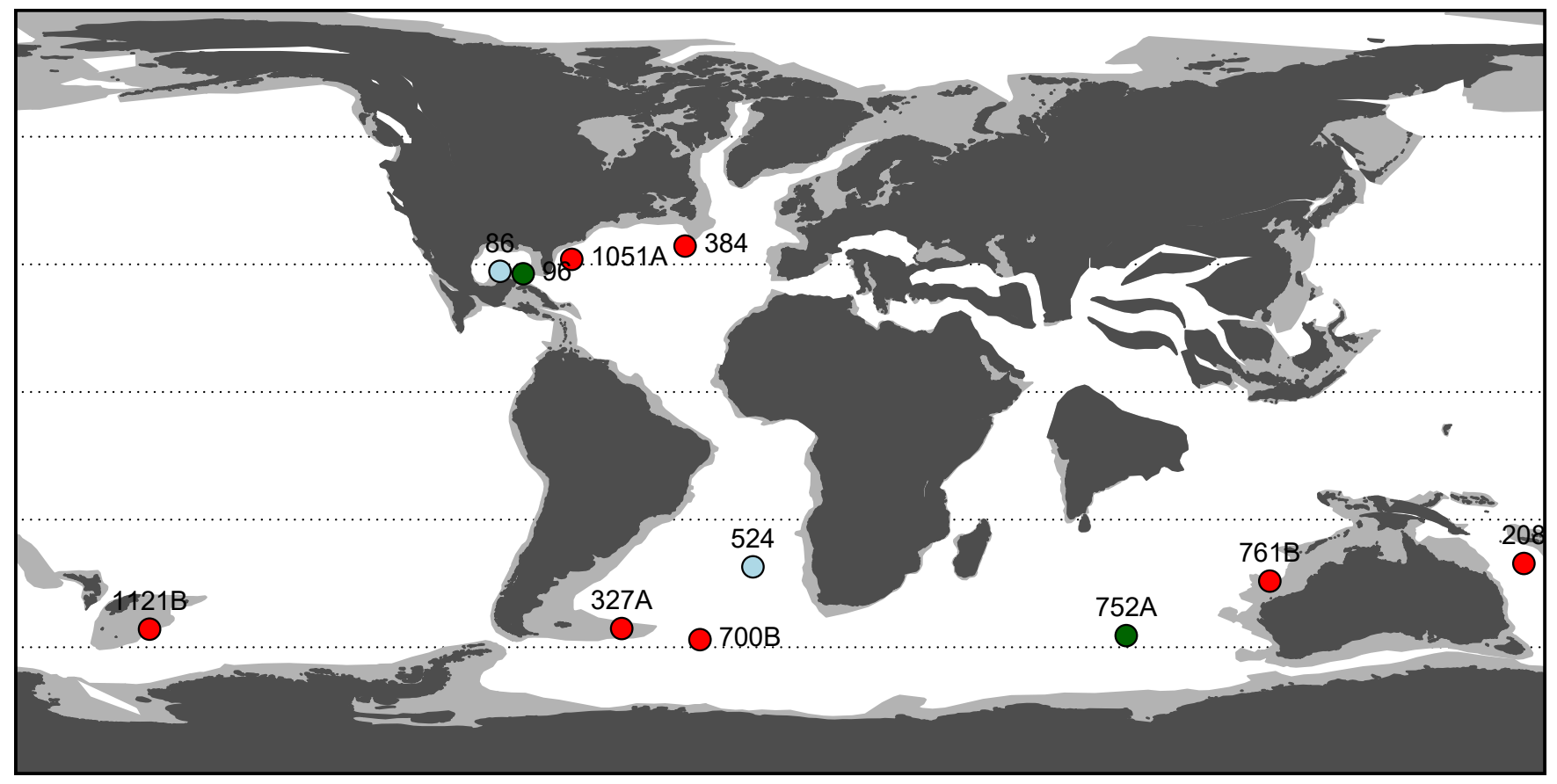

Figure 1. Paleocene map of studied sites. The red dots represent sites for which both the abundance and the taxonomic composition of diatoms were studied; blue is sites at which only the abundance was studied and green is sites at which only the taxonomic composition was studied. The palaeogeographic map was produced using Gplates (Boyden et al., 2011) along with the Wright et al. (2013) rotation model.

\section{Material and method}

Siliceous microfossils (diatoms, radiolarians, sponge spicules, silicoflagellates and others) were counted on strewn slides from DSDP sites 86, 208, 327A, 384, 524 and ODP sites 700B, 761B, 1051A and 1121B, and diatom occurrences were observed and identified at the species level in strewn slides from DSDP sites 96, 208, 327A, 384 and ODP sites 700B, 752A, 761B, 1051A and 1121B (see Fig. 1).

These slides all belong to the Micropaleontological Reference Center (MRC, Lazarus, 2006) hosted in Berlin, a working collection of slides from the DSDP and ODP campaign, made for radiolarian research. The studied sites were thus selected based on sample availability in the MRC collection. The DSDP slides were produced at the Scripps Institution of Oceanography with $63 \mu \mathrm{m}$ sieves, while the ODP slides were produced in part at the Museum für Naturkunde in Berlin and in part at Utsunomiya University, in both cases with $45 \mu \mathrm{m}$ sieves. Because of the use of relatively large-sized sieves, the smallest fraction of diatoms is thus unlikely to be present on the slides, making the reported abundance and diversity of diatoms a strict minimum. To avoid complications arising from the variety of methods used to produce these slides (random vs. non-random settling, unknown amount of material used), only the diatom/radiolarian ratio is reported here, instead of absolute abundances (see Fig. 2), which tells us what proportion of biogenic opal is composed of diatoms. Counts were performed until there were at least 1000 specimens (when possible) on at least two tracks (see Supplement for more details) at $\times 200$ magnification. A species occurrence table can be found in Table S1 and the taxonomic list, with comments and synonymies, in Appendix A. Family assignments of diatom genera in the text follow Nikolaev et al. (2001).

The age models of all sites come either from the NSB database (Lazarus, 1994) or were made for this study using NSB_ADP_wx (available at https://github.com/plannapus/ nsb_adp_wx/releases, version 0.6.1, last access: 1 December 2017, and based on the ADP software; Lazarus, 1992; Bohling, 2005) and are given, with details on the biostratigraphic data used to produce them, as a Supplement. All ages are calibrated to the Gradstein et al. (2012) geomagnetic polarity timescale.

The diversity (i.e. species richness) curve shown in Fig. 4 was produced using the same methodology as in Lazarus et al. (2014) - updated in Wiese et al. (2016) - using Shareholder Quorum Subsampling (SQS; Alroy, 2010) with a quota of 0.7 repeated on 500 trials, corrected using the D80 metrics (Lazarus et al., 2014), and time bins of 1 million years. Diversity curves subsampled in half-a-millionyear time bins are also available in the Supplement to allow direct comparison with Lazarus et al. (2014). Two curves are shown: the red one shows the diversity calculated in Wiese et al. (2016) using data from the Neptune NSB database (Lazarus, 1994, http://nsb-mfn-berlin.de, last access: 27 March 2018) and the black one shows the data 


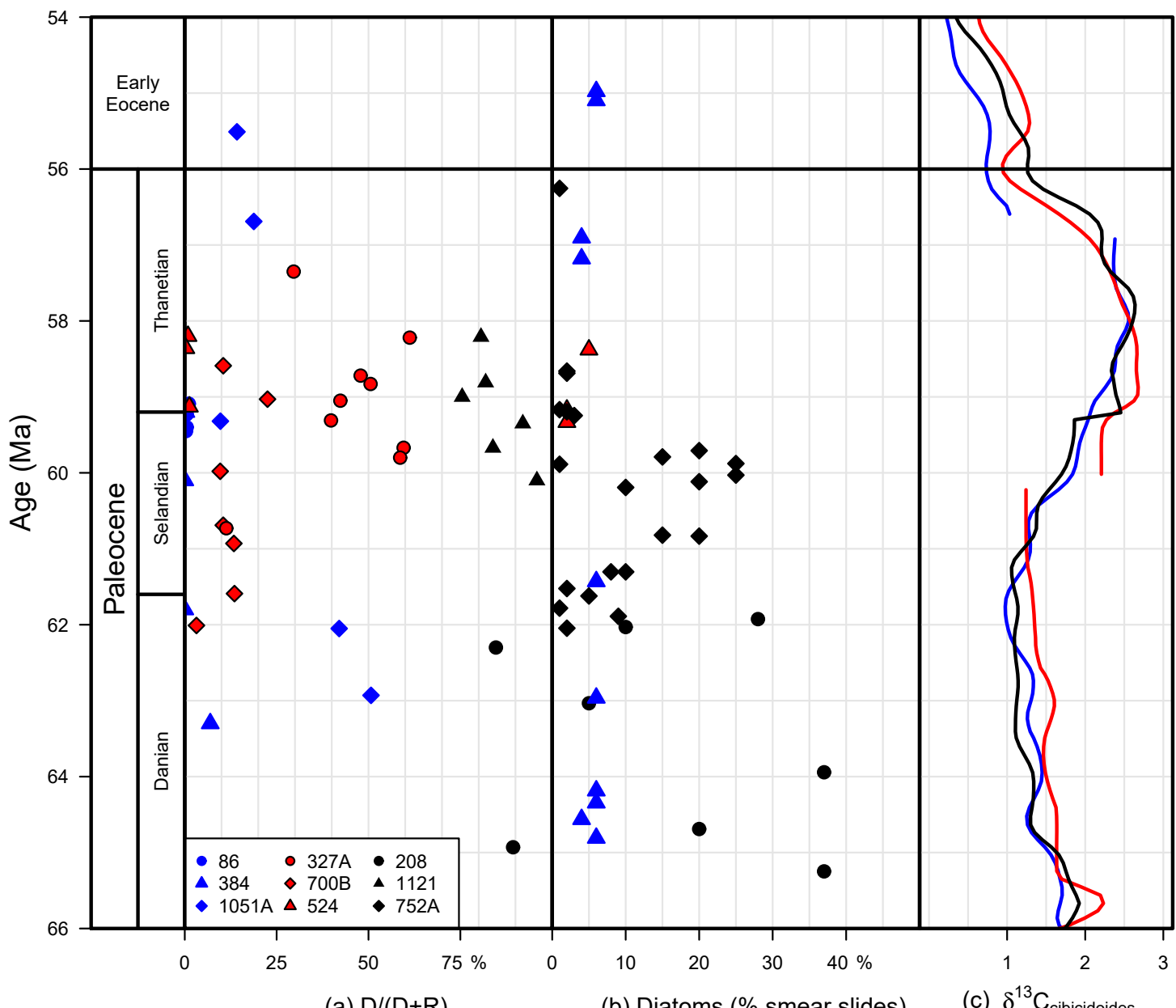

Figure 2. Paleocene diatom relative abundance record. (a) shows diatom abundance relative to radiolarian abundance (expressed as a percentage) measured in samples from the MRC collection slides (this study). Panel (b) shows absolute diatom abundance as a percentage of the components of the sediment, as estimated in smear slides by the Leg scientific staff (from the Inital Reports, as synthesized in National Geophysical Data Center, 2000, 2001). Nine sites are shown in both panels: three from the Southern Ocean (Pacific and Indian Ocean sectors, in black), three in the Southern Atlantic (red) and three in the North Atlantic (blue). Panel (c) shows $\delta^{13} \mathrm{C}$ trends as reported in Cramer et al. (2009) for the Southern Ocean (black), the South (red) and North (blue) Atlantic.

from the NSB database as it stands in 2018 and the addition of the occurrence data from this study. Open-nomenclature taxa from NSB or from this study were both discarded from the diversity analysis. The small differences outside of the early Paleogene that can be seen between the two species diversity curves are due to changes in the age models present in the database: since mid-2016, ca. 80 age models were added or modified in the NSB database. Despite those small differences (namely a flatter late Oligocene), the primary pattern after the early Eocene remains unchanged from Wiese et al. (2016). Making an age model for Site 752A in this study also allowed for the addition, in the black diversity curve, of the Fourtanier (1991) data set.

A cohort analysis based on the occurrences of the species found during this study is also shown in Fig. 3: the number of species originating in the Cretaceous is compared to the num- ber of species originating in the Cenozoic for the Paleocene to earliest Eocene time interval. In this graph, the diversity of each age cohort is shown on the left, and the individual species ranges on which the diversity is calculated is shown on the right. On the right, species ranges are extended based on literature data: in particular, they are extended toward the Cretaceous when known to be present in the Cretaceous (see "Results" section for detailed literature references on Cretaceous occurrences) and toward the Eocene when known to be present in sediments younger than the early Eocene (based primarily on the data from the NSB database). An additional, similar cohort analysis based not only on the species found during this study but also all species reported in the NSB database for the same time interval is given in the Supplementary Material: despite the addition of the smaller taxa 


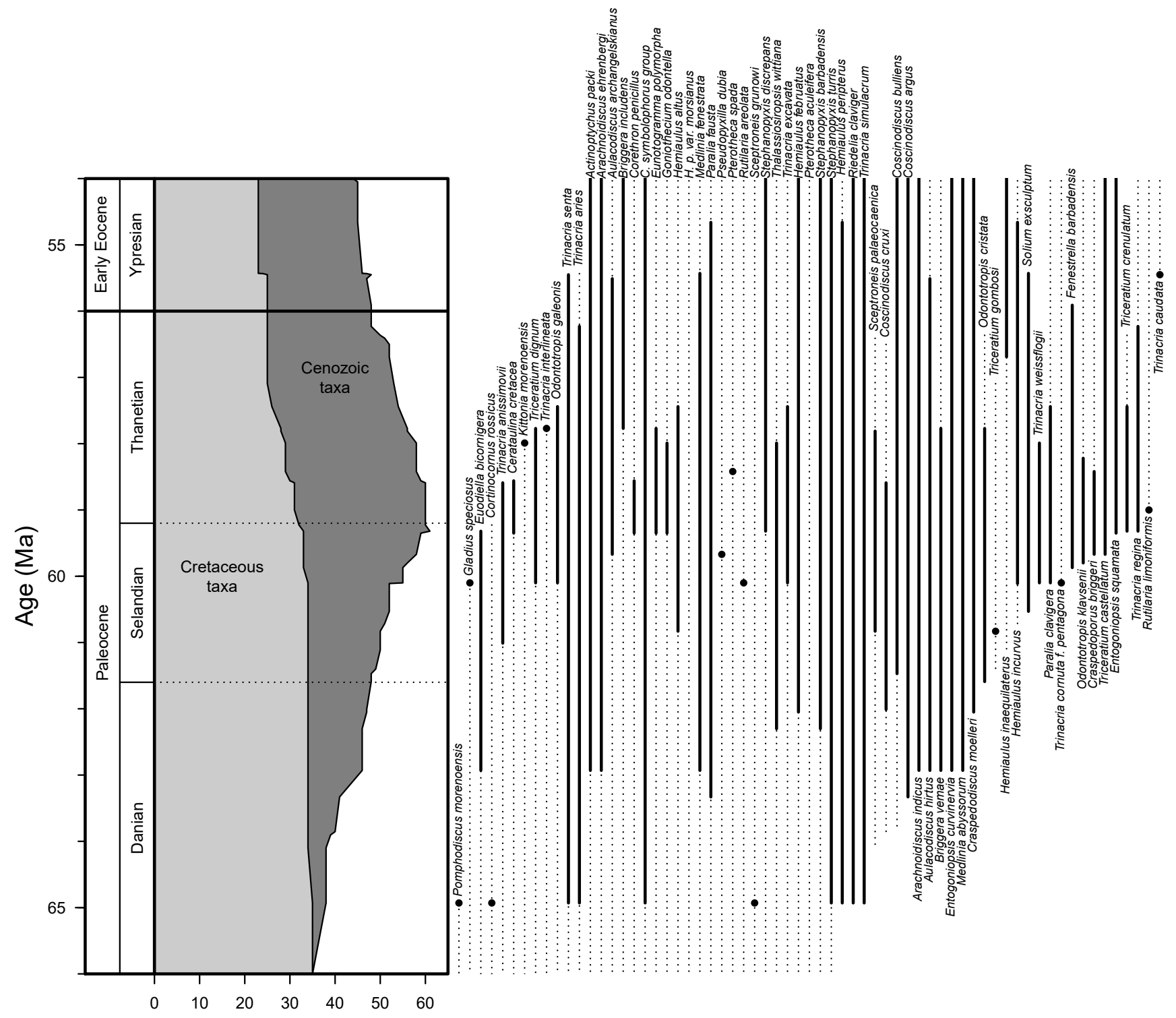

Figure 3. Cohort analysis. Ranges observed in this study are plotted as thick lines or black dots while dashed lines correspond to species range extension based on data from the literature.

not recovered here, the pattern is similar if not identical to the one observed in Fig. 3.

\section{Results}

\subsection{Abundances}

The samples explored here primarily show that diatoms were already a significant portion of the biogenic silica during the Paleocene (Fig. 2). The high-latitude southwest Pacific sites 208 and 1121 exhibit consistently high diatom/radiolarian ratios (i.e. diatom relative abundance) throughout the time interval covered by the available sam- ples (early Paleocene and early Eocene for Site 208 and middle to late Paleocene for Site 1121). This observation mirrors similar observations of increased diatom/radiolarian ratios in land sections in New Zealand (Hollis et al., 1995, 2003a, b). Similarly, the midlatitude North Atlantic Site 1051A contains a large proportion of diatoms from the early Paleocene to the early Eocene, although the ratio declines noticeably over the course of the studied time series. The two other North Atlantic sites (86 and 384), however, have comparably low relative abundance of diatoms in the studied early Paleogene samples, even if they do contain a few specimens. High-latitude South Atlantic samples finally exhibit an interesting pattern: while Site 524, on the Walvis Ridge, is over- 
all scarce in diatoms, sites 700B and 327A (on the Falkland Plateau) both contain a fair proportion of diatoms during the middle Paleocene, and while this proportion remains stable in 700B up to the late Paleocene, Site 327A shows a dramatic increase that seems coeval with a known regional increase in $\delta^{13} \mathrm{C}$ prior to the middle-late Paleocene boundary (Cramer et al., 2009), which itself is also coeval with a biotic crisis referred to as the mid-Paleocene biotic event (see e.g. Petrizzo, 2005; Bernaola et al., 2007). On the other hand, smear slides from the Indian sector Site 752A (Shipboard Scientific Party, 1989; National Geophysical Data Center, 2001) show that absolute diatom abundance (regardless of radiolarians) was high during the middle Paleocene and plummets at about the same time as the $\delta^{13} \mathrm{C}$ increases.

Finally, although the values measured in this study and reported in the first panel of Fig. 2, being diatom/radiolarian ratios, could be mostly controlled by variations in radiolarian abundances, values of absolute diatom abundance in the sediment as reported in smear slide analyses (specifically for sites 208 and 384 Shipboard Scientific Party, 1973, 1979; National Geophysical Data Center, 2000) show in fact that observed high and low diatom/radiolarian ratios do seem to correspond to some extent to respectively high and low diatom absolute abundance.

\subsection{Assemblages composition and diversity}

Of the 104 species encountered, 68 previously described species were identified. Thirty-five of those are known from Cretaceous sediments: Actinoptychus packi (in Nikolaev et al., 2001), Arachnoidiscus ehrenbergi (in Nikolaev et al., 2001), Aulacodiscus archangelskianus (in Nikolaev et al., 2001), A. pugnalis (in Hanna, 1927), Briggera includens (in Witkowski et al., 2011), Cerataulina cretacea (in Hajós and Stradner, 1975), Corethron penicillus (through its synonymy with Skeletonemma subantarctica Hajós and Stradner; see Fenner, 1994), Coscinodiscus symbolophorus group, Eunotogramma polymorpha (in Harwood, 1988), Euodiella bicornigera (in Hanna, 1927; Nikolaev et al., 2001), Gladiopsis speciosus (in e.g. Nikolaev et al., 2001; Witkowski et al., 2011), Goniothecium rogersii (in Zalat, 2013, as G. odontella), Hemiaulus altus (in Hajós and Stradner, 1975), H. februatus (according to Barron et al., 2015), H. polymorphus var. morsianus (in Harwood, 1988), Cortinocornus rossicus (in Harwood, 1988), Kittonia morenoensis (see Brigger and Hanna, 1965), Medlinia fenestrata (in Witkowski et al., 2011), Paralia fausta (in Hanna, 1927; Witkowski et al., 2011), Odontotropis galeonis (in Hanna, 1927; Nikolaev et al., 2001), Phomphodiscus morenoensis (in e.g. Nikolaev et al., 2001), Pseudopyxilla dubia (in Harwood, 1988), Pterotheca aculeifera (in Harwood, 1988; Witkowski et al., 2011), Pterotheca spada (in Harwood, 1988), Sceptroneis grunowi? (in Harwood, 1988), Stephanopyxis barbadiensis (in Nikolaev et al., 2001), S. discrepans? (in Nikolaev et al., 2001), S. turris (in Nikolaev et al., 2001; Zalat, 2013), Thalassiosiropsis wittiana (in e.g. Nikolaev et al., 2001), Trinacria aries (in Harwood, 1988; Nikolaev et al., 2001), T. anissimovii (in Hajós and Stradner, 1975), T. excavata (in Nikolaev et al., 2001; Witkowski et al., 2011), T. interlineata (in Hajós and Stradner, 1975, as T. tristictia), T. senta (in Harwood, 1988; Sims and Ross, 1988), Triceratium dignum (in Hajós and Stradner, 1975) and Rutilaria areolata (in Ross, 1995).

Though the presence of some of those species in the Paleocene could be due to reworking, most of them appear in numerous, continuous sections, either in this study or in the literature (e.g. Cortinocornus rossicus in Fenner, 1991), or are even known in younger sediments. Indeed, of these 35 species, most survived the Paleocene and are still present in Eocene sediments, with the exception of Aulacodiscus pugnalis, Cerataulina cretacea, Euodiella bicornigera, Gladiopsis speciosus, Hemiaulus februatus, Hemiaulus polymorphus var. morsianus, Kittonia morenoensis, Odontotropis galeonis, Phomphodiscus morenoensis, Trinacria interlineata and Triceratium dignum, which are not known in sediments younger than the Paleocene. Gladiopsis speciosus alone is only found in a single-sample herein and is not known in the literature on Cenozoic sediments and thus could reasonably be considered a reworked specimen, though the observed specimen does not seem to show any more alteration than other specimens from the same sample.

Only 11 previously described species found in our material are restricted to Paleocene sediments: Coscinodiscus cruxii, Hemiaulus peripterus, Fenestrella barbadensis, Odontotropis cristata and O. klavsenii, Pseudotriceratium fallax, Sceptroneis palaeocenica, Solium exsculptum, Trinacria weissfloggi, Triceratium crenulatum and $T$. gombosi.

In addition to these 11 named species, 36 species were left here in open nomenclature. As these species were not found in the literature, one can assume that most of them are restricted to Paleocene sediments. Those species are briefly described and illustrated herein, in the taxonomic Appendix.

Overall the number of Cretaceous species present in the studied samples diminishes slowly and gradually during the Paleocene (see Fig. 3), still representing up to $40 \%$ of the total number of species at the end of the Paleocene.

In all of the observed samples containing a substantial community (i.e. excluding sites 86 and 524), assemblages were dominated by species of Hemiaulales (specifically species of genera Trinacria and Hemiaulus, with T. senta being particularly abundant in Southern Ocean samples) and Stephanopyxales (mainly the genera Triceratium and Stephanopyxis). Only some samples from Site 700B differed from this pattern and contained a large number of broken specimens of Coscinodiscales, outweighing any other groups.

When the occurrence data from the named species in this study are added to the diatom data from the NSB database (see Fig. 4), the resulting subsampled species diversity pattern show a Paleocene diversity level as high as in the early 


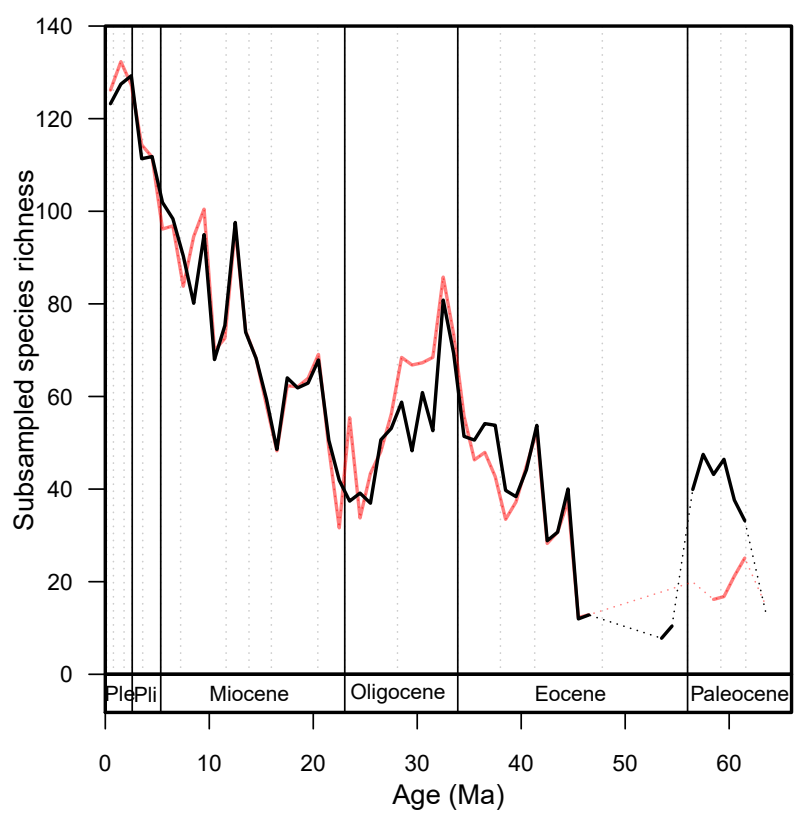

Figure 4. Species diversity of planktonic diatoms as analysed in Wiese et al. (2016) (in red) and in this study (in black), based on NSB occurrence data and the current data set. As some time bins do not contain enough occurrences to accurately estimate their diversity, discontinuous time bins are connected with dotted lines.

late Eocene, twice as high as what was estimated in previous analyses (Lazarus et al., 2014; Wiese et al., 2016). The diversity level recovered at the beginning of the early Eocene seems to drop drastically; however given the low number of early Eocene samples included in the study, it may well be an artifact.

\subsection{Stratigraphic notes}

In Fourtanier (1991), a biostratigraphic zonation was proposed, splitting the Paleocene and earliest part of the Eocene in two zones (Hemiaulus peripterus zone and H. incurvus zone), based on the first occurrences of Hemiaulus incurvus. In our material, the FO of $H$. incurvus occurs on Site $752 \mathrm{~A}$ between samples $27-1,33(60.11 \mathrm{Ma})$ and 284,43 (60.83 Ma), and was reported in Fourtanier (1991) between samples 28-2,100 (60.71 Ma) and 28-3,55 (60.77 Ma). Similarly it is found here at Site 372 between samples 72,128 (59.8 Ma) and 9-1,112 (60.73 Ma), at Site 700B between samples 30-1,70 (59.98 Ma) and 30-6,24 (60.69 Ma), and at Site 1121B, where it appears prior to sample 12-2,51 (60.1 Ma). The Hemiaulus incurvus zone is further split in three subzones by the last occurrences of Trinacria aries and Triceratium gombosii var. A. While the latter was not found in our material, the former occurs on Site $752 \mathrm{~A}$ between sample 21-1,70 (56.23 Ma) and sample 20-1,55 (55.43) and after sample 6-2,120 (57.44 Ma) on Site 1121B. On two other sites where T. aries is found in our study (327A and 700B), however, it occurs earlier, at ca. 58 Ma. Gombos Jr. (1977) also proposed a biostratigraphic zonation for the Paleocene based on Site 327A using the total range of species Odontotropis klavsenii and the first occurrence of Hemiaulus inaequilaterus. O. klavsenii however was only found, in this study, in Site 327A (where it indeed appears between 60.73 and 59.8 Ma and disappears between 58.22 and $57.73 \mathrm{Ma}$ ). As for H. inaequilaterus, we only found it in Site 1051A, where it appears between samples 60-2,46 (59.32 Ma) and $56-2,46(56.69 \mathrm{Ma})$, but it was reported in Fenner (1991) down to $60.1 \mathrm{Ma}$ on Site 700B.

\section{Discussion}

The observed patterns of relative and absolute diatom abundance in this study suggest that, similarly to the later part of the Paleogene (Renaudie, 2016), the main loci of deepsea diatom deposition occurred already in the Paleocene in discrete patches in the Southern Ocean - mainly in the southwest Pacific but also during part of the Paleocene in the South Atlantic or the Indian sectors - and to a lesser extent in the North Atlantic. Similarly, the reanalysis of the Cenozoic diatom diversity, including this study's data, shows a Paleocene diversity comparable to that of the early late Eocene and even of the late Oligocene (Fig. 4). Given the additional fact that the assemblages studied here, as mentioned in the Material and methods section, probably underestimate the smallest fraction of diatom diversity and that a significant proportion of the studied assemblages were left in open nomenclature (since, precisely, these assemblages, prior to this paper, were understudied) and thus discarded from the analysis, it is possible that the actual diversity of the Paleocene, relative to the Eocene, could be even higher, thus giving a significantly different picture of diatom macroevolution than previously considered (Katz et al., 2004; Lazarus et al., 2014; Barron et al., 2015).

The diversity curve (Fig. 4) seems to show an abrupt decrease in the earlier Eocene, with diversity remaining low until the middle Eocene. Given the scarcity of data during this time period - only a few samples were studied here for the early Eocene and barely 15 samples come from a single site (752A from Fourtanier, 1991) were retrieved from NSB - it is entirely possible that this decrease is artificial. In fact, reports from the Paleocene-Eocene transition on the Russian epicontinental platform (Oreshkina and Oberhaensli, 2003; Oreshkina and Aleksandrova, 2007; Oreshkina, 2012; Oreshkina and Radionova, 2014) reported floral changes during the earliest part of the Eocene, such as the loss of various Cretaceous species, but also the appearance of new Eocene species. It is not clear, however, if this event happened worldwide or was restricted to this epicontinental sea. Unfortunately, as the early Eocene is marked by widespread cherts and thus very few deep-sea sites contain usable siliceous microflora (Muttoni and Kent, 2007), we are currently unable to 
quantitatively confirm any decrease or increase in diversity in the early Eocene.

Despite the radical change in subsampled diversity in the early Paleogene, the strong correlation between diatom diversity and $\delta^{18} \mathrm{O}$ (as proxy for Cenozoic temperature changes, from Zachos et al., 2008) observed and discussed in Lazarus et al. (2014) and in Wiese et al. (2016) is still observed here (with a Spearman's $\rho=0.873, p<2 \times 10^{-16}$; and when linearly detrended $\left.\rho=0.604, p=1.48 \times 10^{-6}\right)$. If this relationship is correct, it would then indeed make sense for early Eocene diatom diversity to plummet, given $\delta^{18} \mathrm{O}$ is at its lowest (and thus temperature at its highest) during the early Eocene climatic optimum (EECO; see e.g. Zachos et al., 2008).

The cohort analysis presented in Fig. 3 is the first globalscale documentation of the Cretaceous-Cenozoic transition in oceanic diatom assemblage compositions. It suggests a fairly continuous, stable extinction rate during the Paleocene with no clear extinction event of Cretaceous species, and a slow speciation rate, since Cenozoic species still only account for less than half of the total species at the end of the Paleocene. This indicates a slow, gradual turnover in planktonic diatoms from the Cretaceous to the Eocene. This finding confirms the observation of Harwood (1988) from local sections on Seymour Island (Antarctica) of a large overlap of Late Cretaceous and early Paleocene microflora and the low probability of any significant extinction event at the Cretaceous-Paleocene boundary (Harwood, 1988; MacLeod et al., 1997). Not only were the assemblages still mostly composed of Cretaceous species until the beginning of the Eocene, but the taxonomic composition of the assemblages, in particular with the dominance of orders Hemiaulales and Stephanopyxales, is also coherent with the composition of Late Cretaceous assemblages (Nikolaev and Harwood, 2002; Harwood et al., 2007), implying a smooth, continuous floral transition from the Late Cretaceous to the early Eocene. This continuum echoes what is known in radiolarians. Indeed the final Cretaceous event is not marked by an increased extinction rate in radiolarians (Hollis, 1991, 1993, 1996) and Cretaceous radiolarian species are only known to start disappearing at a higher rate in the late Paleocene (Hollis, 1997).
The discrepancy between previous estimates of Paleocene planktonic diatom diversity and the one computed here highlights once again the systematic underreporting of taxa in the literature and the need to report biodiversity for the sake of biodiversity, and not as a by-product of stratigraphic analyses (Lazarus, 2011) in order to study macroevolutionary patterns.

\section{Conclusions}

The idea that diatom diversity increased progressively since the beginning of the Cenozoic and that marine planktonic diatoms became widespread only at the middle Eocene might therefore need to be revised: not only are the Paleocene diatom assemblages at least as diverse as late Eocene ones but the geographical abundance pattern observed in the $\mathrm{Pa}$ leocene show no strong differences with the one observed 15 million years later in the Bartonian. Whether or not this corresponds to a continuous period of stable diversity and abundance pattern from the Paleocene to the late middle Eocene, however, cannot be certified given our almost complete absence of data for the early Eocene.

Finally, here we can quantitatively confirm the gradual turnover of Cretaceous species and their high survivorship among planktonic diatoms up until at least the Ypresian, as was hypothesized by Harwood (1988) and MacLeod et al. (1997).

Code and data availability. The data gathered during this study, the literature data extracted from Neptune NSB database and used for the diversity computations, as well as the biostratigraphic data and the line of correlations (i.e. age models) for the studied sites are all available as a Supplement. The NSB_ADP_wx software used to produce the age model is available on GitHub: https://github.com/ plannapus/nsb_adp_wx/releases (Renaudie and Diver, 2017).

The Supplement related to this article is available online at https://doi.org/10.5194/fr-21-183-2018-supplement. 


\section{Appendix A: Systematic palaeontology}

Bacillariophyta Engler and Gilg

Class Coscinodiscophyceae Round and Crawford

Genus Actinocyclus Ehrenberg

Actinocyclus sp. (Plate A4.20)

Remarks. This species possesses a central hyaline area, and a large number of radially arranged rows of closely packed areolas.

Genus Actinoptychus Ehrenberg

Actinoptychus packi Hanna (Plate A1.5,8)

Actinoptychus packi Hanna (1927), pl. 1 figs. 1-

3; Nikolaev et al. (2001), pl. 9, figs. 1-4.

Genus Arachnoidiscus Deane ex Shadbolt

Arachnoidiscus indicus Ehrenberg (Plate A1.10)

Arachnoidiscus indicus Ehrenberg (1854), pl. 36, fig. 1; Long et al. (1946), pl. 14, fig. 9.

Arachnoidiscus ehrenbergi J. W. Bailey (Plate A1.11)

Arachnoidiscus ehrenbergi Bailey in Ehrenberg (1849), p. 64; Nikolaev et al. (2001), pl. 31, figs. 15.

Genus Asterolampra Ehrenberg

Asterolampra sp. (Plate A1.18)

Remarks. This species resembles the middle Eocene species Asterolampra marylandica Ehrenberg with the exception that it possesses a large number of radial arrays and an extraneous small array wedged between two of the main arrays (reminiscent of the one found in genus Asteromphalus) but does not reach the central part of the valve.

Genus Aulacodiscus Ehrenberg

Aulacodiscus archangelskianus Witt (Plate A1.1)

Aulacodiscus archangelskianus Witt (1885); Long et al. (1946), pl. 14 fig. 13; Nikolaev et al. (2001), pl. 17 figs. 1-6.

Aulacodiscus hirtus J. W. Barker and S. H. Meakin (Plate A1.2)

Aulacodiscus hirtus Barker and Meakin (1949), pl. 37, fig. 1.

Aulacodiscus pugnalis Hanna (Plate A1.3)
Aulacodiscus pugnalis Hanna (1927), pl. 1, figs. 6-7; Aulacodiscus sp. cf. A. insignis Hustedt in Witkowski et al. (2011), fig. 7A-B.

Aulacodiscus sp. A (Plate A1.4)

Remarks. This species is characterized by radially arranged, densely packed arrays of small areolas, a central depression and a raised roll near the margin, on which areolas are more numerous and denser. Five to eight small hyaline areas are present on this roll, from which tubular processes rise.

\section{Aulacodiscus sp. cf. A. pugnalis Hanna \\ (Plate A1.6)

$$
\text { cf. Aulacodiscus pugnalis Hanna (1927). }
$$

Genus Auliscus Ehrenberg

Auliscus spp. (Plate A1.19)

Remarks. Determination at the species level of this group was not attempted. The few specimens found had between 2 and 4 ocelli near their margin. They only differed by the number of ocelli, all other observable characters being otherwise identical.

\author{
Genus Biddulphia Gray \\ Biddulphia corpulenta Greville (Plate A2.8-9) \\ Biddulphia corpulenta Greville (1865), pl. 6 \\ fig. 16; Williams (1988), pl. 22, fig. 6.
}

Biddulphia sp. (Plate A2.4)

Remarks. The species resembles Biddulph primordialis Long, Fuge and Smith (Long et al., 1946, pl. 17, fig. 19) with the exception that it has a smooth outline (by opposition of B. primordinalis dented outline).

Genus Briggera Ross and Sims

Briggera includens (Grunow) R. Ross and P. A. Sims (Plate A2.1)

Hemiaulus includens Grunow (1884); Briggera includens (Grunow) Ross and Sims (1985), pl. 1, figs. 1-9; Hemiaulus ornithocephalus Schmidt var. in Homann (1991), pl. 18, fig. 14.

Briggera vemae R. Ross and P. A. Sims (Plate A2.2)

Briggera vemae Ross and Sims (1985), pl. 7, figs. 1-9, pl. 31, fig. 3.

Briggera sp. A (Plate A2.5-6) 


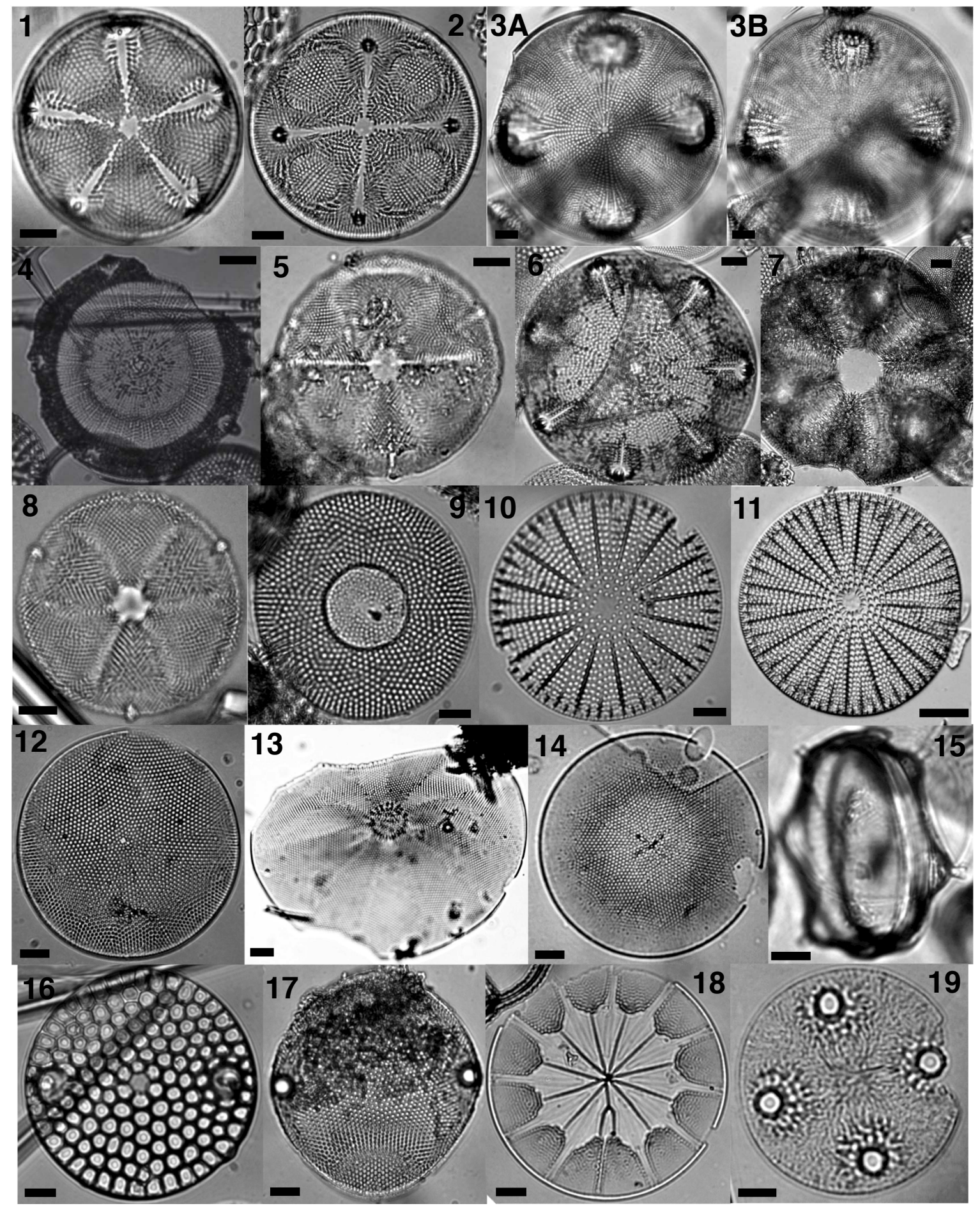

Plate A1. (1) Aulacodiscus archangelskianus Witt. (2) Aulacodiscus hirtus J. W. Barker and S. H. Meakin. (3A-B) Aulacodiscus pugnalis Hanna. (4) Aulacodiscus sp. A. (5, 8) Actinoptychus packi Hanna. (6) Aulacodiscus sp. cf. A. pugnalis. (7) Craspedoporus briggeri R. Ross and P. A. Sims. (9) Pomphodiscus morenoensis (J. A. Long, D. P. Fuge, and J. Smith) J. W. Barker and S. H. Meakin. (10) Arachnoidiscus indicus Ehrenberg. (11) Arachnoidiscus ehrenbergi J. W. Bailey. (12-14) Coscinodiscus symbolophorus Grunow group. (15) Aulacodiscus? sp. (16) Eupodiscus sp. A. (17) Eupodiscus sp. B. (18) Asterolampra sp. (19) Auliscus spp. Samples 208-30-2,66 (9, 12), 208-31-3,28 (13), 327A-8-3,52 (14), 1051A-53-2,45 (16), 1051A-56-2,46 (1, 2, 8, 19), 1051A-64-2,47 (5), 1051A-67-2,47 (10, 11, 17), 1121B-8-2,60 (18), 1121B-9-5,100 (4), 1121B-11-1,80 (6, 15) and 1121B-11-4,100 (3A-B, 7). Scale bar: $10 \mu \mathrm{m}$. 


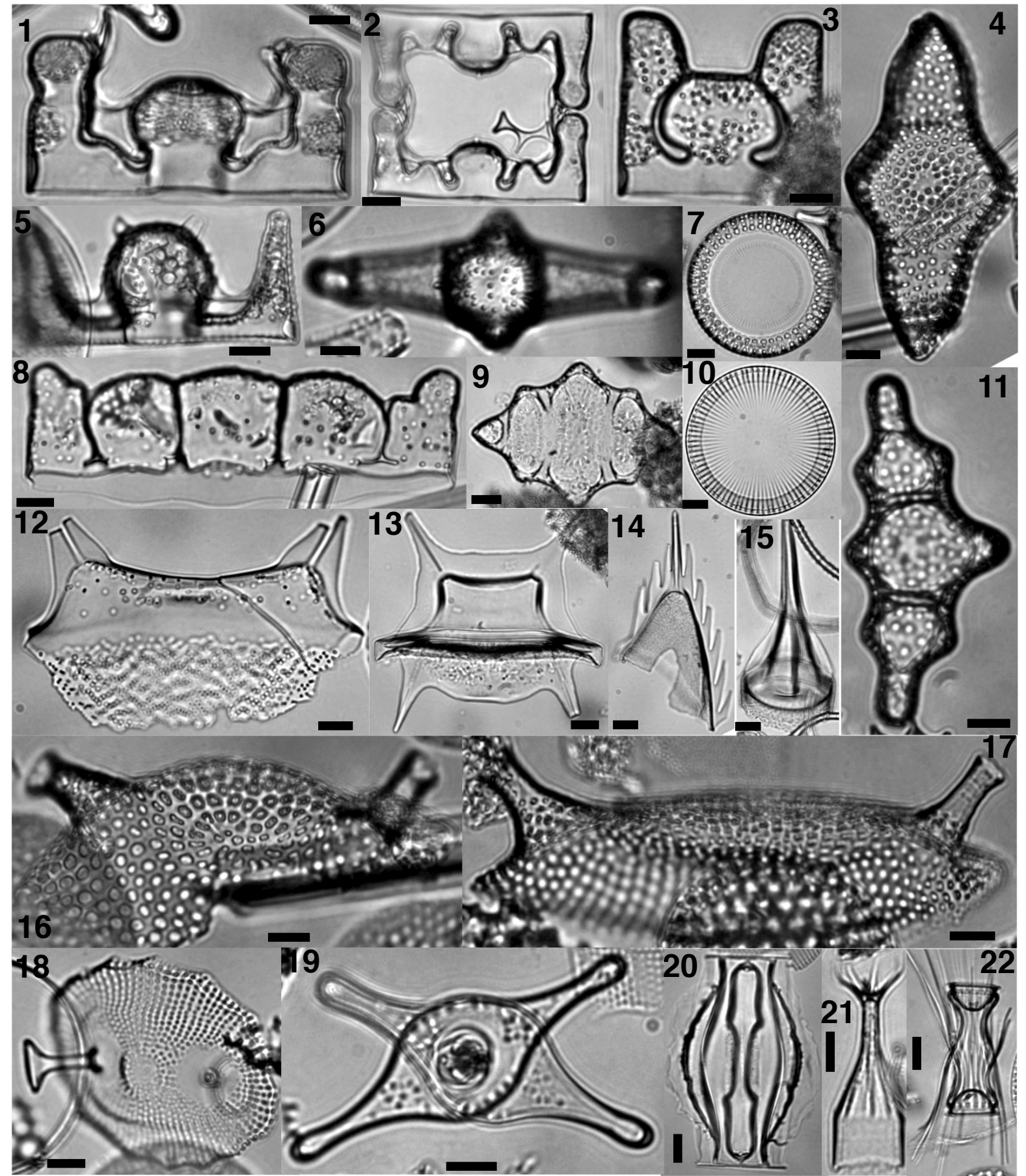

Plate A2. (1) Briggera includens (Grunow) R. Ross and P. A. Sims. (2) Briggera vemae R. Ross and P. A. Sims. 3) Porpeia sp. (4) Biddulphia sp. (5-6) Briggera sp. A, in lateral view (5) and in apical view (6). (7) Paralia fausta (Schmidt) P. A. Sims and Crawford. (89) Biddulphia corpulenta, in lateral view (8) and in apical view (9). (10) Paralia clavigera (Grunow) Koizumi. (11) Eunotogramma polymorpha? (12) Odontotropis galeonis Hanna. (13) Odontotropis klavsenii Debes ex Hustedt. (14) Odontotropis cristata (Grunow) Grunow. (15) Kentrodiscus sp. (16-17) Kittonia sp. A. (18) Kittonia morenoensis Brigger and Hanna. (19) Rutilaria areolata Sheshukova-Poretskaya in Sheshukova-Poretskaya and Glezer. (20) Goniothecium rogersii Ehrenberg. (21) Cerataulina cretacea Hajós. (22) Corethron penicillus (Grunow) J. Fenner, two epivalves interlocked. Samples 327A-7-2,17 (9, 13), 1051A-45-CC,14 (1), 1051A-53-2,45 (8), 1051A-56-2,46 (7), 1051A-60-2,46 (4), 1121B-7-1,100 (2, 5, 14), 1121B-7-5,30 (6, 12, 18, 20), 1121B-8-5, 100 (17), 1121B-9-1,100 (16, 21, 22), 1121B-10-2,50 (11), 1121B-11-4,100 (10, 15) and 1121B-12-2,51 (19). Scale bar: $10 \mu \mathrm{m}$. 
Remarks. The central portion of this species of Briggera is almost spherical, with two apical projections. The two opposite elevated portions of the valve are conical. No connecting spines have been observed on any specimens. A velum connects the central portion to the elevated portions of the valve.

Genus Cerataulina Peragallo ex Schütt in Engler and Prantl

Cerataulina cretacea Hajós (Plate A2.21)

Cerataulina cretacea Hajós in Hajós and Stradner (1975), pl. 10 figs. 3-4.

Genus Corethron Castracane

Corethron penicillus (Grunow) Fenner (Figs. A2.22, A3.16)

Skeletonema? penicillus Grunow in van Heurck (1882); Sims (1994a), figs. 37-40, 53; Skeletonema subantarctica Hajós in Hajós and Stradner (1975), pl. 2 fig. 1; Corethron penicillus (Grunow) Fenner (1994), pl. 4, fig. 4.

Genus Cortinocornus Gleser

Cortinocornus rossicus (Pantocsek) Gleser

Hemiaulus rossicus Pantocsek (1889); Fenner (1991), p. 138, 8, fig. 11-14; Harwood (1988), pl. 14, fig. 18-21; pl. 15, fig. 4-5; Cortinocornus rossicus Gleser (1984), p. 290.

Genus Coscinodiscus Ehrenberg

Coscinodiscus bulliens Schmidt (Plate A4.22)

Coscinodiscus bulliens Schmidt (1887); Hajós 1976, pl. 6, fig. 5-6; Fenner (1991), pl. 9 fig. 6.

Coscinodiscus cruxii Fenner (Plate A4.21)

Coscinodiscus cruxii Fenner (1991), pl. 11 fig. 26.

Coscinodiscus argus Ehrenberg (Plate A5.2)

Coscinodiscus argus Ehrenberg (1838); Hustedt (1930), fig. 226.

Coscinodiscus sp. C (Fig. A4.23)

Coscinodiscus symbolophorus Grunow group (Plate A1.12-14)

Coscinodiscus symbolophorus Grunow (1884), pl. 4 fig. 3-6; Coscinodiscus morenoensis Hanna (1927); Harwood (1988), pl. 10 fig. 15-16; Symbolophora microtrias Ehrenberg in Homann (1991), pl. 40 fig. 12-13, pl. 41 fig. 1-2, 4-5; Azpeitiopsis morenoensis (Hanna) Nikolaev et al. (2001), pl. 21 fig. 1-6.
Remarks. Given the variety in the number and the disposition of the central labiate processes observed near the central depression on the specimens' valves (see differences between Plate A1.12, 13 and 14), it is possible that this is not a single species but a group of species. Unfortunately, since many specimens are only observed as fragments from which the central depression is absent, we did not judge possible to differentiate them consistently in this study.

Genus Craspedodiscus Ehrenberg

Craspedodiscus moelleri Schmidt (Plate A5.3)

Craspedodiscus moelleri Schmidt (1887), Gombos Jr. (1977), pl. 27, fig. 6.

Genus Craspedoporus Greville

Craspedoporus briggeri R. Ross and P. A. Sims (Plate A1.7)

Craspedoporus briggeri Ross and Sims (2000), fig. 60-69.

Genus Entogoniopsis J. Witkowski, P. A. Sims, N. I. Strelnikova and D. M. Williams

Entogoniopsis squamata (Pantocsek) J. Witkowski, P. A. Sims, N. I. Strelnikova and D. M. Williams (Plate A3.14, 24)

Triceratium squamatum Pantocsek (1889); Entogoniopsis squamata (Pantocsek) Witkowski et al. (2015), fig. 108-16.

Entogoniopsis curvinervia (Boyer) J. Witkowski, P. A. Sims, N. I. Strelnikova and D. M. Williams (Plate A3.10)

Biddulphia curvinervia Coyer 1922; Entogoniopsis curvinervia (Boyer) Witkowski et al. (2015), fig. 214.

Genus Eunotogramma Weisse

Eunotogramma polymorpha? (Plate A2.11)

?Eunotogramma polymorpha Strelnikova (1965); Harwood (1988), pl. 10, fig. 17-18.

Genus Euodiella Sims

Euodiella bicornigera (Hanna) P. A. Sims (Plate A3.19)

Triceratium bicornigerum Hanna (1927), pl. 3 fig. 13-14; Euodiella bicornigera (Hanna) Sims (2000), fig. 1-6, 50-51. 
Genus Eupodiscus Bailey

Eupodiscus sp. A (Plate A1.16)

Remarks. This species resembles the specimen illustrated as Eupodiscus barbadiensis Greville in Williams (1988) (pl. 38, fig. 1) but differs from it by the two ocelli that are considerably smaller in our species and by the presence of a small hyaline area in the centre of the valve.

\section{Eupodiscus sp. B (Plate A1.17)}

Remarks. Valves are subcircular with two opposite ocelli touching the margin, and are perforated by densely packed rows of small areolas disposed in a direction perpendicular to the ocellus-to-ocellus axis.

Genus Fenestrella Greville

Fenestrella barbadensis? (Plate A5.1)

? Fenestrella barbadensis Greville (1863), p. 68, fig. 8; Gombos Jr. (1984), pl. 6, fig. 1-4; Williams (1988), pl. 39, fig. 2.

Genus Gladiopsis Gersonde and Harwood

Gladiopsis speciosus (Schultz) Gersonde and Harwood (Plate A4.14)

Gladius speciosus Schulz (1935); Hajós and Stradner (1975), pl. 11, fig. 5-6; Harwood (1988), pl. 10, fig. 24; Gladiopsis speciosus (Schulz) Gersonde and Harwood (1990); Tapia and Harwood (2002), pl. 5, fig. 1-4.

Genus Goniothecium Ehrenberg

Goniothecium rogersii Ehrenberg (Plate A2.20)

Goniothecium rogersii Ehrenberg (1843); Suto et al. (2008), figs. 3-40; Goniothecium odontella Ehrenberg (1844); Hajós (1976), pl. 17, fig. 13, pl. 25, fig. 1-2; Gombos Jr. (1977), pl. 40, fig. 9.

Genus Hemiaulus Ehrenberg

Hemiaulus altus Hajós (Plate A3.23)

Hemiaulus altus Hajós and Stradner (1975), p. 931, pl. 5, fig. 17-19; Fenner (1991), pl. 4, fig. 3.

Hemiaulus februatus Heiberg (Plate A4.8)

Hemiaulus februatus Heiberg (1863); Homann (1991), pl. 18, figs. 12-13.

Hemiaulus inaequilaterus Gombos

Hemiaulus inaequilaterus Gombos Jr. (1977), pl. 20, fig. 5-7.
Hemiaulus incurvus Schibkova (Plate A4.1)

Hemiaulus incurvus Krotov and Schibkova (1959); Mukhina (1976), pl. 1, fig. 1-3; Gombos Jr. (1977), Pl. 16, fig. 6-7, Pl. 17, fig. 1-3.

Hemiaulus peripterus Fenner (Plate A4.2)

Hemiaulus peripterus Fenner (1984), p. 332, pl. 1, fig. 8-9; Fenner (1991), pl. 7, fig. 9.

Hemiaulus polymorphus Grunow var. morsianus Grunow

Hemiaulus polymorphus Grunow var. morsianus Grunow (1884); Harwood (1988), pl. 14, fig. 12 .

Remarks. This species was only found in the early Eocene samples of this study.

$$
\begin{aligned}
& \text { Hemiaulus sp. A (Plate A4.6, 17) } \\
& \text { Hemiaulus sp. } 2 \text { Fenner (1991), pl. 6, fig. 8-9. }
\end{aligned}
$$

Remarks. This species is characterized by long polar elevations possessing large, blade-like linking spines. The rest of the valve does not seem to bear pseudosepta; however a cluster of small, needle-like spines project from the central part of the valve. A narrow velum joins the two linking spines by closely following the outline of the valve.

Genus Kentrodiscus Pantocsek

Kentrodiscus sp. (Plate A2.15)

Genus Kittonia Glove and Sturt

Kittonia morenoensis Brigger and Hanna (Plate A2.18)

Kittonia morenoensis Brigger and Hanna (1965), p. 7, fig. 4.

Kittonia sp. A (Plate A2.16-17)

Remarks. This rather large species has large, subquadratic, radially arranged areolas. The valve is trapezoidal and bears two large, hollow projections that are cylindrical, with a widened base, and that flare distally. The projections bears areolas at their bases but are hyaline afterwards. They are situated at the beginning of the slope of the valve and are directed upward at a low angle. The central part of the valve is slightly depressed. The valve margin has not been observed on any of the specimens encountered.

Genus Medlinia Sims

Medlinia abyssorum (Grunow) P. A. Sims (Plate A3.12) 


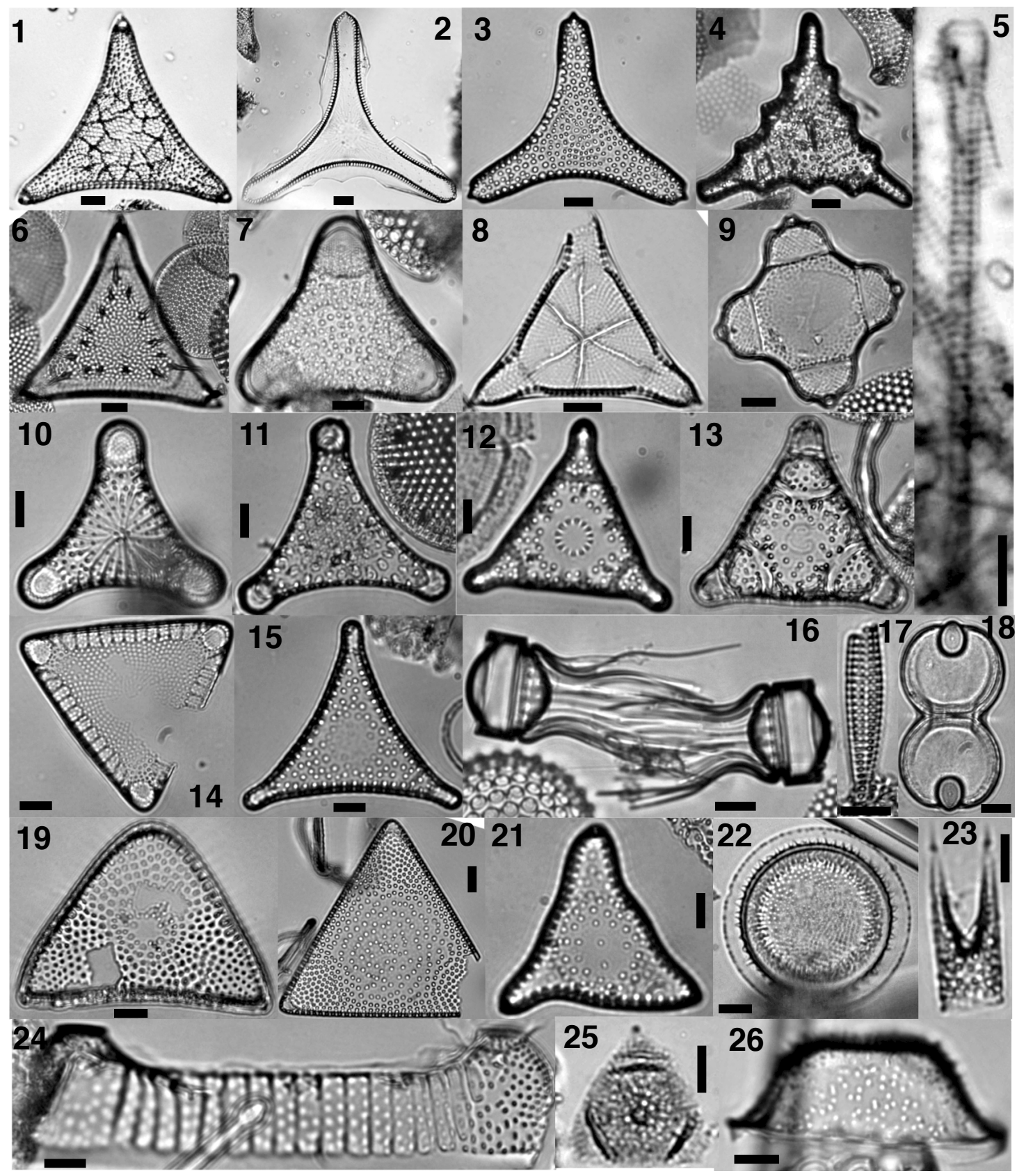

Plate A3. (1) Trinacria senta (Witt) P. A. Sims and R. Ross. (2) Trinacria simulacrum E. Grove and G. Sturt. (3) Trinacria anissimovii Jousé. (4) Triceratium crenulatum E. Grove and G. Sturt. (5) Sceptroneis palaeocenica (Jousé) J. Fenner. (6) Trinacria weissflogii Witt. (7) Triceratium castellatum T. West. (8) Trinacria interlineata Long, Fuge and Smith. (9) Solium exsculptum Heiberg. (10) Entogoniopsis curvinervia (Boyer) J. Witkowski, P. A. Sims, N. I. Strelnikova and D. M. Williams. (11) Trinacria aries Schmidt. (12) Medlinia abyssorum (Grunow) P. A. Sims. (13) Medlinia fenestrata (Witt) P. A. Sims. (14, 24) Entogoniopsis squamata (Pantocsek) J. Witkowski, P. A. Sims, N. I. Strelnikova and D. M. Williams, in apical view (14) and in lateral view (24). 15) Medlinia sp. A. (16) Corethron penicillus (Grunow) J. Fenner. (17) Sceptroneis grunowi? (18) Resting spore sp. C. (19) Euodiella bicornigera (Hanna) P. A. Sims. (20) Sheshukovia sp. A. (21) Triceratium dignum Long, Fuge and Smith sensu Hajós and Stradner (1975). (22, 26) Pseudopodosira? sp. A, in apical view (22) and in lateral view (26). (23) Hemiaulus altus Hajós. (25) Triceratium sp. Samples 208-31-3,28 (17), 327A-5-1,50 (25), 327A-6-4,108 (23), 327A-7-2, 17 (1, 2), 327A-8-1,112 (3), 700B-29-1,75 (5), 1051A-45-CC,14 (10, 12), 1051A-53-2,45 (24), 1051A-56-2,46 (14, 22), 1051A60-2,46 (19), 1121B-7-1,100 (8, 20, 26), 1121B-7-5,30 (9, 18, 21), 1121B-8-2,60 (11), 1121B-9-1,100 (4, 13, 16), 1121B-10-2,50 (15), 1121B-11-1,80 (6) and 1121B-11-4,100 (7). Scale bar: $10 \mu \mathrm{m}$. 
Triceratium abyssorum Grunow (1884); Sheshukovia abyssorum (Grunow) Fenner (1994), pl. 10 fig. 6; Medlinia abyssorum (Grunow) Sims (1998), fig. 51-57.

Medlinia fenestrata (Witt) P. A. Sims (Plate A3.13)

Triceratium fenestratum Witt (1885); Sheshukovia fenestrata (Witt) Fenner (1994), pl. 10 fig. 9; Medlinia fenestrata (Witt) Sims (1998), fig. 45-50, 58-89.

Medlinia sp. A (Plate A3.15)

Remarks. This species differs from Medlinia deciusii (Hanna) Nikolaev and Kociolek (see in Nikolaev et al., 2001, pl. 27, fig. 4-6) in lacking (pseudo-)septa.

\section{Genus Paralia Heiberg}

Paralia clavigera (Grunow) Koizumi (Plate A2.10)

Melosira clavigera Grunow (1884); Hajós (1976), pl. 1, fig. 3-4, pl. 2, fig. 3-4; Paralia clavigera (Grunow) Koizumi (1992).

Paralia fausta (Schmidt) P. A. Sims and Crawford (Plate A2.7)

Melosira fausta Schmidt (1887); Hanna (1927), pl. 3, fig. 11-14; Paralia fausta (Schmidt) Sims and Crawford (2002); Witkowski et al. (2011), fig. $6 \mathrm{G}$.

Genus Odontotropis Grunow

Odontotropis cristata (Grunow) Grunow (Plate A2.14)

Biddulphia? cristata Grunow in van Heurck (1882); Odontotropis cristata (Grunow) Grunow (1884), pl. 5 fig. 58; Dell'Agnese and Clark (1994), pl. 9 fig. 9; Oreshkina and Radionova (2014), pl. 13 fig. 10 .

Odontotropis galeonis Hanna (Plate A2.12)

Odontotropis galeonis Hanna (1927), pl. 4 fig. 1-3; Nikolaev et al. (2001), pl. 35 fig. 4-6.

Odontotropis klavsenii Debes ex Hudstedt (Plate A2.13)

Odontotropis klavsenii Debes ex Hustedt (1930), fig. 510a; Gombos Jr. (1977), pl. 39 fig. 14.

Genus Pomphodiscus Barker and Meakin
Phomphodiscus morenoensis (J. A. Long, D. P. Fuge, and J. Smith) J. W. Barker and S. H. Meakin (Plate A1.9)

Craspedodiscus morenoensis Long et al. (1946), pl. 17 fig. 1; Pomphodiscus morenoensis (Long, Fuge and Smith) Barker and Meakin 1946, pl. 5 fig. 6; Nikolaev and Harwood (2000), pl. 1 fig. 1-6, pl. 2 fig. 7; Nikolaev et al. (2001), pl. 22 fig. 1-5.

Genus Porpeia Bailey ex Ralfs

Porpeia sp. (Plate A2.3)

Remarks. This species differs from Terpsinoe anguinea Long et al. (1946) in its two elevated portions of the valve extending higher than its central part, covering it partially by widening distally. This species was only found in the early Eocene samples of this study.

Genus Pseudopodosira Jousé in ProschinaLavrenko

Pseudopodosira? sp. A (Plate A3.22, 26)

Remarks. This morphospecies is hat-shaped in the frontal view, circular in apical view, with a hyaline margin, and with the upper portion of the valve covered by small knob-like protuberances.

Genus Pseudopyxilla Forti

Pseudopyxilla dubia (Grunow) Forti

Pyxilla dubia Grunow (1884); Pseudopyxilla dubia (Grunow) Forti (1909); Harwood (1988), pl. 17, fig. 23-24.

Genus Pseudotriceratium Grunow

Pseudotriceratium fallax Grunow

Pseudotriceratium fallax Grunow (1884), p. 83; Homann (1991), pl. 32 fig. 1, 5-9; Fenner (1994), pl. 10 fig. 8 .

Genus Pterotheca Grunow ex Forti

Pterotheca spada Tempère and Brun

Pterotheca spada Tempère and Brun in Brun and Tempère (1889); Harwood (1988), pl. 18, fig. 24-25.

Genus Pyxilla Greville

Pyxilla gracilis Tempére and Forti 
Pyxilla gracilis Tempére and Forti in Forti (1909), pl. 2, fig. 5; Fourtanier (1991), pl. 4, fig. 10; Pyrgupyxis gracilis (Tempére and Forti) Hendey; Fenner (1978), pl. 19, fig. 1-3.

Remarks. This species was only found in the early Eocene samples of this study.

Genus Riedelia Jousé and Sheshukova-Poretzkaja

Riedelia claviger (Schmidt) Schrader and Fenner (Plate A4.7)

Hemiaulus claviger Schmidt (1887); Riedelia claviger (Schmidt) Schrader and Fenner (1976), pl. 41, fig. 6-8, 9, pl. 42, fig. 3-4, 10-11, 15 .

Genus Rutilaria Greville

Rutilaria areolata Sheshukova-Poretskaya in Sheshukova-Poretskaya and Glezer (Plate A2.19)

Rutilaria areolata Sheshukova-Poretskaya in Scheschukova-Poretzkaja and Gleser (1964); Ross (1995), fig. 31-32, pl. 7, fig. a-d.

Rutilaria limoniformis?

? Rutilaria limoniformis Ross (1976); Ross (1995), fig. 13-14.

Genus Sheshukovia Gleser

Sheshukovia sp. A (Plate A3.20)

Remarks. This species is triangular, has somewhat densely packed areolas near its apices, and more sparse ones close to the centre of the valve.

Genus Solium Heiberg

Solium exsculptum Heiberg (Plate A3.9)

Solium exsculptum Heiberg; Ross and Sims (1987), pl. 1, pl. 12 figs. 86-88; Trinacria exsculpta (Heiberg) Hustedt (1930), fig. 533; Gombos Jr. (1984), pl. 8, fig. 9-1.

Genus Stephanopyxis (Ehrenberg) Ehrenberg

Stephanopyxis barbadensis (Greville) Grunow (Plate A4.3)

Cresswellia barbadensis Greville (1865), pl. 1, fig. 11; Stephanopyxis barbadensis (Greville) Grunow (1884); Nikolaev et al. (2001), pl. 4, fig. 1-6.

Stephanopyxis sp. A (Plate A4.12)
Remarks. This species has a circle of spines toward the apex, has relatively large, polygonal areolas, a narrow hyaline margin and the row of areolas closed to the margin is elongated.

Stephanopyxis sp. B (Plate A4.13)

Remarks. This species has a cylindrical shape, with a circle of spines at the slope break and small, linearly arranged, circular areolas.

\section{Stephanopyxis sp. C (Plate A4.4)}

Remarks. This species is almost flat, with a circle of projections close to the margin. Instead of tapering distally like spines, the projections eventually flatten, and on occasion, give rise to small lateral processes.

\section{Stephanopyxis sp. E (Plate A4.5)}

Remarks. This species, from above, has a sub-elliptical to globular outline. Areolas are small and closely packed. There is a ring of spines/projections close to the apex.

Stephanopyxis sp. F (Plate A4.19)

?Stephanopyxis sp. B in Harwood (1988), pl. 20 fig. 2.

Remarks. This species is hemispherical, has small, closely packed areolas and a remarkably thick shell. No spines have been clearly observed so far.

Stephanopyxis sp. G (Plate A4.18)

Remarks. This species, though similar to Stephanopyxis sp. A (above), differs from it in its less numerous, larger polygonal areolas, and the absence of the ring of spines. On several occasions, valves, presumably from different specimens of a chain, have been found (as in the illustrated specimens) still closely attached, but no apparent processes have been observed at the magnification at which we worked, linking both valves.

\section{Stephanopyxis sp. H (Plate A4.10)}

Remarks. This species is hemispherical, with small, closely packed areolas and a ring of spines close to the apex, as in Stephanopyxis sp. A.

Stephanopyxis discrepans? (Plate A4.9)

? Stephanopyxis discrepans Hanna (1927), pl. 4, fig. 10-11; Nikolaev et al. (2001), pl. 5, fig. 1-6, pl. 6, fig. 1-6.

Stephanopyxis turris (Greville) Ralfs in Pritchard (Plate A4.15)

Cresswellia turris Greville; Stephanopyxis turris (Greville) Ralfs in Pritchard; Gombos Jr. (1977), pl. 2, fig. 5; Nikolaev et al. (2001), pl. 7, fig. 5-6. 


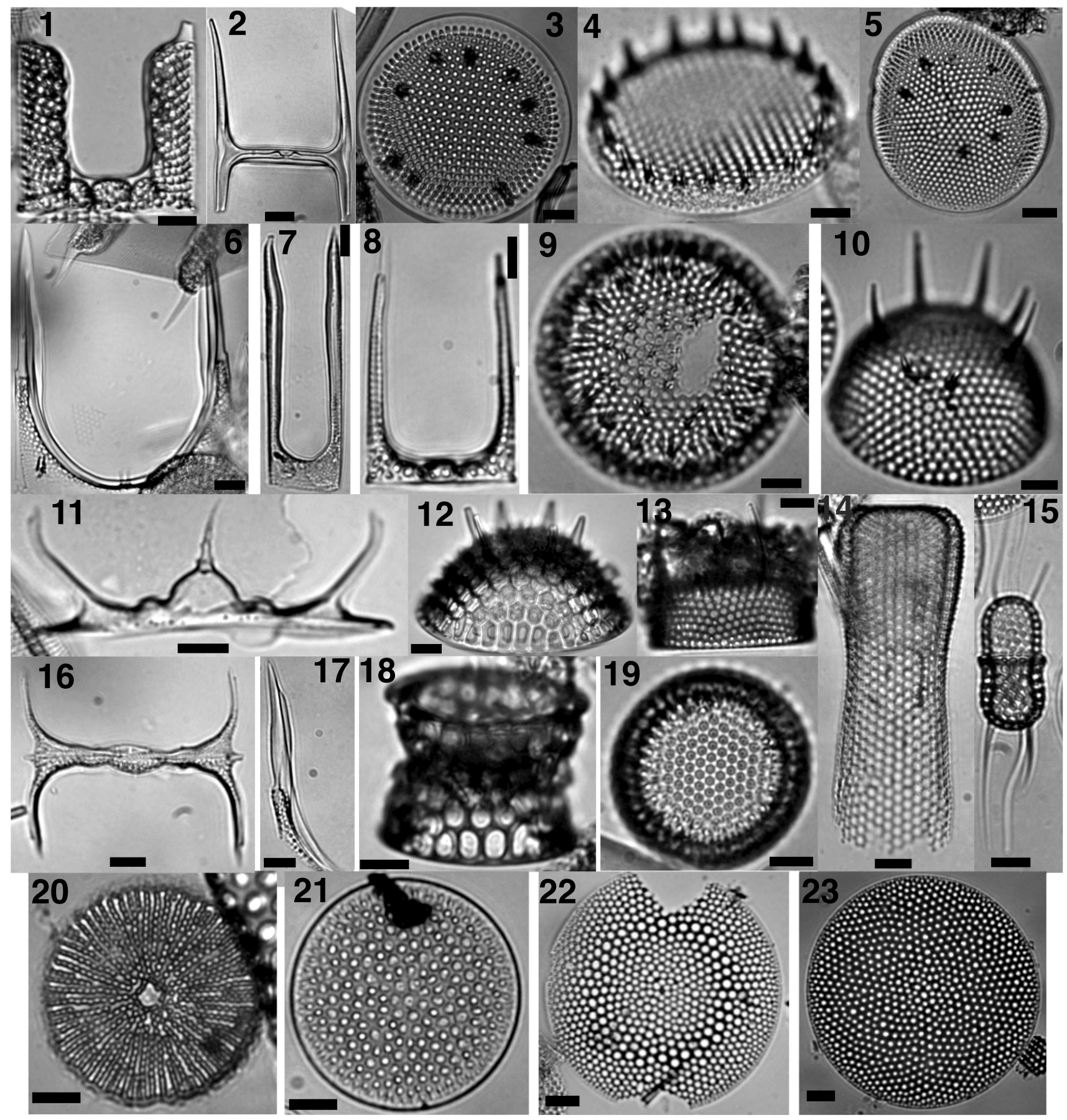

Plate A4. (1) Hemiaulus incurvus Shibkova. (2) Hemiaulus peripterus J. Fenner. (3) Stephanopyxis barbadiensis (Greville) Grunow. (4) Stephanopyxis sp. C. (5) Stephanopyxis sp. E. (6, 17) Hemiaulus sp. A. (7) Riedelia claviger Schmidt. (8) Hemiaulus februatus Heiberg. (9) Stephanopyxis discrepans? (10) Stephanopyxis sp. H. (11) Hemiaulus? sp. (12) Stephanopyxis sp. A. (13) Stephanopyxis sp. B. (14) Gladius speciosus P. Schulz. (15) Stephanopyxis turris (Greville) Ralfs. (16) Hemiaulus sp. (18) Stephanopyxis sp. G. (19) Stephanopyxis sp. F. (20) Actinocyclus sp. (21) Coscinodiscus cruxii J. Fenner. (22) Coscinodiscus bulliens Schmidt. (23) Coscinodiscus sp. C. Samples 208-281,65 (22), 327A-5-6,28 (13, 23), 327A-7-2, 17 (18), 700B-28-4, 111 (8, 21), 700B-31-1,60 (20), 1051A-45-CC,14 (9), 1051A-53-2,45 (19), 1051A-56-2,46 (2), 1051B-67-2,47 (5), 1121B-7-1,100 (12), 1121B-8-2,60 (17), 1121B-8-5,100 (7, 10), 1121B-9-1,100 (4), 1121B-10-2,50 (3), 1121B-11-4,100 (1) and 1121B-12-2,51 (6, 11, 14, 15, 16). Scale bar: $10 \mu \mathrm{m}$. 
Genus Thalassiosiropsis Hasle in Hasle and Syvertsen

Thalassiosiropsis wittiana (Pantocsek) Hasle ex Hasle and Syvertsen (Plate A5.4)

Coscinodiscus wittianus Pantocsek; Thalassiosiropsis wittiana (Pantocsek) Hasle ex Hasle and Syvertsen; Sims (1994b), figs. 29-36; Nikolaev et al. (2001), pl. 1, fig. 1-4.

Genus Triceratium Ehrenberg

Triceratium castellatum West (Plate A3.7)

Triceratium castellatum West 1860; Hanna (1927), pl. 21 fig. 4.

Triceratium crenulatum Grove and Sturt (Plate A3.4)

Triceratium crenulatum Grove and Sturt (1886a), pl. 2 fig. 3; Gombos Jr. (1977), pl. 38 fig. 2.

Triceratium gombosi Fenner

Triceratium gracillium Hustedt sensu Gombos Jr. (1977), pl. 37 fig. 1-2; Triceratium gombosii Fenner (1991), pl. 1 fig. 7, pl. 9 fig. 1-2.

Triceratium sp. (Fig. A3.25)

Remarks. All the specimens found in this study were very thin, as if partially dissolved. The species is triangular in outline, with slightly concave sides. The vertices of the outline are separated from the central part by what could be septa, halfway through. There is a central, circular structure similar to what Greville (1864) described for Triceratium attenuatum.

Triceratium dignum J. A. Long, D. P. Fuge, and J. Smith (Plate A3.21)

Triceratium dignum Long et al. (1946), pl. 17 fig. 15, pl. 18 fig. 10; Hajós and Stradner (1975), pl. 8 fig. $7-8$.

Genus Trinacria Heiberg

Trinacria anissimovii Jousé (Plate A3.3)

Trinacria anissimovii Jousé (1949); Trinacria anissimowii Jousé in Hajós and Stradner (1975), pl. 10, fig. 2.

Trinacria aries Witt (Plate A3.11)

Trinacria aries Witt (1885); Schmidt (1887), pl. 96 fig. 14-18; Hanna (1927), pl. 5 fig. 1-2; Hajós and Stradner (1975), pl. 9 fig. 9-1; Harwood (1988), fig. 21.14.
Trinacria caudata (Witt) P. A. Sims and R. Ross

Triceratium caudatum Witt (1885); Trinacria caudata (Witt) Sims and Ross (1988), pl. 10 and 13 fig. 93-94.

Trinacria cornuta (Grev.) P. A. Sims and R. Ross forma pentagona $\mathrm{P}$. A. Sims and R. Ross

Trinacria cornuta forma pentagona Sims and Ross (1988), pl. 12 fig. 79.

Trinacria excavata Heiberg

Trinacria excavata Heiberg (1863), pl. 4, fig. 9; Benda (1965), pl. 24 fig. 11; Gombos Jr. (1977), pl. 37, fig. 6 .

Trinacria interlineata J. A. Long, D. P. Fuge, and J. Smith (Plate A3.8)

Trinacria interlineata Long et al. (1946), pl. 18, fig. 11; Sims and Ross (1988), pl. 4, pl. 12 fig. 8586; Trinacria tristictia Hanna; Hajós and Stradner (1975), pl. 9 fig. 5-6; Harwood (1988), pl. 10 fig. 21.

Trinacria regina Heiberg

Trinacria regina Heiberg (1863), pl. 3, fig. 7; Benda (1965), pl. 24 fig. 12; Gombos Jr. (1984), pl. 3 fig. 1.

Trinacria senta (Witt) P. A. Sims and R. Ross (Plate A3.1)

Triceratium sentum Witt (1885); Schmidt (1887); Harwood (1988), pl. 10 fig. 1-3; Trinacria senta (Witt) Sims and Ross (1988), pl. 8, pl. 13 fig. 91-92.

Trinacria simulacrum Grove (Plate A3.2)

Trinacria simulacrum Grove and Sturt (1886b), pl. 13 fig. 46; Gombos Jr. (1977), pl. 36 fig. 1-4; Gombos Jr. (1984), pl. 4 fig. 8.

Trinacria weissflogii Witt (Plate A3.6)

Trinacria weissflogii Witt (1885); Schmidt (1887), pl. 100, fig. 4.

Genus Incertae generis

Coscinodiscid sp. F

Remarks. Dome-shaped valve with a rough surface. Radially aligned areolas are sparse at the apex but become more numerous as they reach the margin.

Resting spore sp. C (Plate A3.18)

Remarks. Frustules are hyaline, smooth, composed in apical view of two circular parts separated by a central constriction. They bear small projections on opposite sides. 


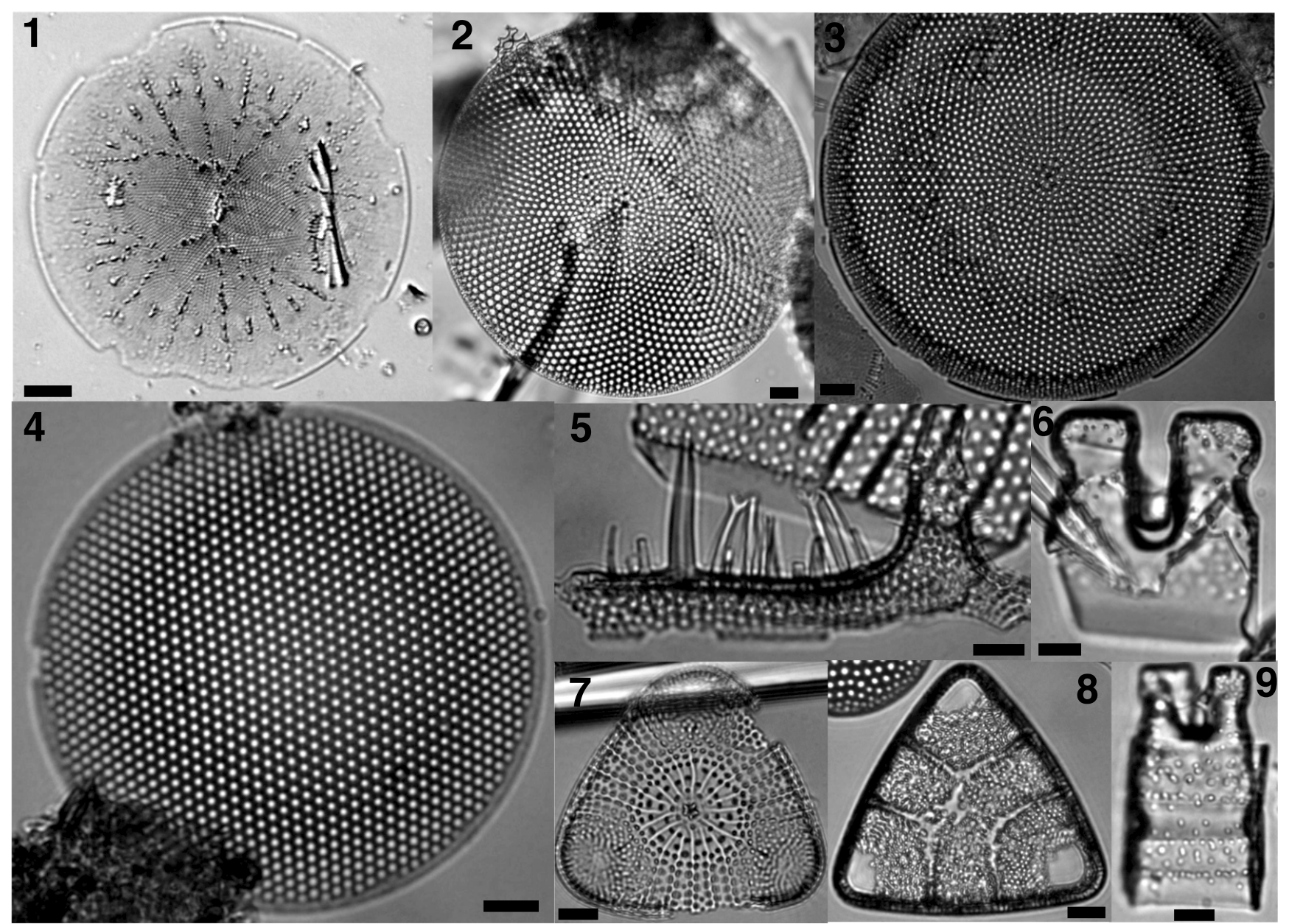

Plate A5. (1) Fenestrella barbadensis? (2) Coscinodiscus argus Ehrenberg. (3) Craspedodiscus moelleri Schmidt. (4) Thalassiosiropsis wittiana (Pantocsek) Hasle. (5) Gen. et sp. indet. sp. A. (6, 9) Gen. et sp. indet. sp. B. (7) Entogoniopsis sp. (8) Pseudotriceratium sp. Samples 327A-6-4,108 (1, 4), 327A-8-3,52 (2), 1051A-45-CC,14 (5), 1051A-53-2,45 (6, 7, 9), 1121B-9-5,100 (8) and 1121B-10-2,50 (3). Scale bar: $10 \mu \mathrm{m}$.

Class Fragilariophyceae Round

Genus Sceptroneis Ehrenberg

Sceptroneis palaeocenica (Jousé) Fenner (Plate A3.5)

Grunowiella palaeocenica Jousé (1951); Fenner (1991), pl. 11, fig. 1-4; Sceptroneis palaeocenica (Jousé) (Fenner, 1994), pl. 7, fig. 3.

Sceptroneis grunowi? (Plate A3.17)

? Sceptroneis grunowi Anissimova; Gombos Jr. (1977), pl. 13, fig. 3-4.

Incertae sedis

Gen. et sp. indet. A (Plate A5.5)

Remarks. These fragments resemble "Genus and species uncertain \#1" and "Genus and species uncertain \#2" from
Gombos (1983) but lack the velum joining the raised section with the spines arising from the valve. This species was only found in the early Eocene samples of this study.

$$
\text { Gen. et sp. indet. B (Plate A5.6, 9) }
$$

Remarks. Specimens are composed of two (or three) elevated portions similar to that of species from genus Porpeia, except they do not possess a central segment (the space between the elevated parts is narrower than them). The whole valve is elevated (higher than large), possesses some irregular pores on its side and a slight basal constriction halfway toward the margin. This overall morphology is somewhat similar to species of genus Dextradonator (Ross and Sims, 1980) except for the apparent lack of raised, interlocking spines at the apices. 
Author contributions. ELD and SB collected the abundance data. JR, ELD and SB collected taxonomic data (i.e. specimen pictures). JR designed the study, worked out the taxonomy, collected the occurrence data, performed the analysis and wrote the manuscript.

Competing interests. The authors declare that they have no conflict of interest.

Acknowledgements. Johan Renaudie was funded during part of this work with DFG grant RE3470/3-1. The authors would like to thank Clément Coiffard and David Lazarus for comments that improved the manuscript, John Barron and Jakub Witkowski for thorough reviews that greatly improved the manuscript, and for providing access to missing literature, as well as the many scientists who compiled stratigraphic data from the DSDP and ODP primary literature for the Neptune database during the Chronos era.

Edited by: Torsten Scheyer

Reviewed by: Jakub Witkowski and John Barron

\section{References}

Aleksandrova, G., Oreshkina, T., Iakovleva, A., and Radionova, E.: Late Paleocene-Early Eocene diatoms and dinocysts from biosiliceous facies of the middle Trans-Urals region, Stratigr. Geo. Correl.+, 20, 380-404, 2012.

Alroy, J.: Geographical, environmental and intrinsic biotic controls on Phanerozoic marine diversification, Palaeontology, 53, 12111235, 2010.

Baldauf, J. and Barron, J.: Evolution of biosiliceous sedimentation patterns - Eocene through Quaternary: paleoceanographic response to polar cooling, in: Geological History of the Polar Oceans: Arctic Versus Antarctic, edited by: Bleil, U. and Thiede, J., vol. 308 of NATO ASI Series C, 575-607, Springer, Berlin, 1990.

Barker, J. and Meakin, S.: New and rare diatoms, Journal of the Quekett Microscopical Club, Series, 4, 6, 1949.

Barron, J. A., Stickley, C. E., and Bukry, D.: Paleoceanographic, and paleoclimatic constraints on the global Eocene diatom and silicoflagellate record, Palaeogeogr. Palaeocl., 422, 85-100, 2015.

Benda, L.: Diatomeen aus dem Eozän Norddeutschlands, Paläontologische Zeitschrift, 39, 165-187, 1965.

Bernaola, G., Baceta, J. I., Orue-Etxebarria, X., Alegret, L., MartínRubio, M., Arostegui, J., and Dinarès-Turell, J.: Evidence of an abrupt environmental disruption during the mid-Paleocene biotic event (Zumaia section, western Pyrenees), Geol. Soc. Am. Bull., 119, 785-795, 2007.

Bohling, G. C.: Chronos Age-Depth Plot: A Java application for stratigraphic data analysis, Geosphere, 1, 78-84, 2005.

Boyden, J. A., Müller, R. D., Gurnis, M., Torsvik, T. H., Clark, J. A., Turner, M., Ivey-Law, H., Watson, R. J., and Cannon, J. S.: Next-generation plate-tectonic reconstructions using GPlates, in: Geoinformatics: cyberinfrastructure for the solid earth sciences, edited by: Keller, G. and Baru, C., 95-114, Cambridge University Press, Cambridge, UK, 2011.
Brigger, A. and Hanna, G. D.: A review of Kittonia, a genus of diatoms, Occasional papers of the California Academy of Sciences, 50, 1-10, 1965.

Brun, J. and Tempère, J.: Diatomées fossiles du Japon: Espèces marines \& nouvelles des calcaires argileux de Sendaï \& Yedo, vol. 30, Société de physique et d'histoire naturelle de Genève, 1889.

Cermeño, P., Falkowski, P. G., Romero, O. E., Schaller, M. F., and Vallina, S. M.: Continental erosion and the Cenozoic rise of marine diatoms, P. Natl. Acad. Sci. USA, 112, 4239-4244, 2015.

Cervato, C. and Burckle, L.: Pattern of first and last appearance in diatoms: oceanic circulation and the position of polar fronts during the Cenozoic, Paleoceanography, 18, 2003.

Cramer, B. S., Toggweiler, J. R., Wright, J. D., Katz, M. E., and Miller, K. G.: Ocean overturning since the Late Cretaceous: Inferences from a new benthic foraminiferal isotope compilation, Paleoceanography, 24, PA4216, https://doi.org/10.1029/2008PA001683, 2009.

Dell'Agnese, D. J. and Clark, D. L.: Siliceous microfossils from the warm Late Cretaceous and early Cenozoic Arctic Ocean, J. Paleontol., 68, 31-47, 1994.

Ehrenberg, C.: Über die Bildung der Kreidefelsen und des Kreidemergels durch unsichtbare Organismen, Abhandlung Königlich Akademie Wissenschften Berlin, Jahrbuch 1838, 59-147, 1838.

Ehrenberg, C.: Über 2 neue Lager von Gebirgsmassen aus Infusorien als Meeres-Absatz in Nord-Amerika und eine Vergleichung derselben mit den organischen Kreide-Gebilden in Europa und Afrika, Monatsberichte der Königlich Preußischen Akademie der Wissenschaften zu Berlin, Jahre, 1844, 57-97, 1844.

Ehrenberg, C. G.: Verbreitung und Einfluss des mikroskopischen Lebens in Süd-und Nord-Amerika, Abhandlungen der königlichen Akademie der Wissenschaften zu Berlin, 1841, 291445, 1843.

Ehrenberg, C. G.: Mitheilungen über Resultate bei Anwendung des chromatisch-polarisierten Lichtes für mikroskopische Verhältnisse, Verhandlungen der Königlich Preußischen Akademie der Wissenschaften zu Berlin, 1849, 55-75, 1849.

Ehrenberg, C. G.: Die systematische Charakteristik der neuen mikroskopischen Organismen des tiefen atlantischen Oceans, Königlichen Preußischen Akademie der Wissenschaften zu Berlin, Bericht, Jahre, 1854, 236-250, 1854.

Fenner, J.: Cenozoic diatom biostratigraphy of the equatorial and southern Atlantic Ocean, Initial Rep. Deep Sea, 38, 491, 1978.

Fenner, J.: Eocene-Oligocene planktic diatom stratigraphy in the low latitudes and the high southern latitudes, Micropaleontology, 30, 319-342, 1984.

Fenner, J.: Taxonomy, Stratigraphy, and Paleoceanographic Implications of Paleocene Diatoms, in: Proceedings of the Ocean Drilling Program, Scientific Results, edited by: Ciesielski, P. F., Kristoffersen, Y., Clement, B., Blangy, J.-P., Bourrouilh, R., Crux, J. A., Fenner, J. M., Froelich, P. N., Hailwood, E., Hodell, D., Katz, M. E., Ling, H. Y., Mienert, J., Muller, D., Mwenifumbo, C. J., Nobes, D. C., Nocchi, M., Warnke, D. A., and Westall, F., 114, 123-154, Ocean Drilling Program, College Station, TX, 1991.

Fenner, J.: Diatoms of the Fur Formation, their taxonomy and biostratigraphic interpretation-results from the Harre borehole, Denmark, Aarhus Geoscience, 1, 99-131, 1994. 
Fenner, J. M.: Description of a new fossil diatom species, Haslea antiqua (Bacillariophyceae), with comments on its valve structure, and habitat, Nova Hedwigia, 114, 107-124, 2015.

Forti, A.: Studi per una Monografia del genere Pyxilla (Diatomee) e dei generi affini, Tipografia del Seminario, 1909.

Fourtanier, E.: Paleocene and Eocene Diatom Biostratigraphy and Taxonomy of Eastern Indian Ocean Site 752, in: Proceedings of the Ocean Drilling Program, Scientific Results, edited by: Barker, P. F., Kennett, J. P., O'Connell, S., Berkowitz, S., Bryant, W. R., Burckle, L. H., Egeberg, P. K., Fiitterer, D. K., Gersonde, R. E., Golovchenko, X., Hamilton, N., Lawver, L., Lazarus, D. B., Lonsdale, M., Mohr, B., Nagao, T., Pereira, C. P. Q., Pudsey,C. J., Robert, C. M., Schandl, E., Spiej, V., Stott, L. D., Thomas, E., Thompson, K. F. M., and Wise Jr., S. W., 121, 171187, Ocean Drilling Program, College Station, TX, 1991.

Gersonde, R. and Harwood, D. M.: Lower Cretaceous Diatoms from ODP Leg 113 Site 693 (Weddell Sea). Part 1: Vegetative Cells, in: Proceedings of the Ocean Drilling Program, Scientific Results, edited by: Barker, P. F., Kennett, J. P., O'Connell, S., Berkowitz, S., Bryant, W. R., Burckle, L. H., Egeberg, P. K., Fiitterer, D. K., Qersonde, R. E., Qolovchenko, X., Hamilton, N., Lawver, L., Lazarus, D. B., Lonsdale, M., Mohr, B., Nagao, T., Pereira, C. P. Q., Pudsey, C. J., Robert, C. M., Schandl, E., Spiej, V., Stott, L. D., Thomas, E., Thompson, K. F. M., and Wise Jr., S. W., 113, 365-402, Ocean Drilling Program, College Station, TX, 1990.

Gleser, S.: Significance of research on the systematics of diatoms for biostratigraphy and paleogeography, Ezhedognik Vsesoyuznog Paleontologicheskogo Obshchestva, 27, 284-298, 1984.

Gombos, A. M. J.: Middle Eocene diatoms from the South Atlantic, Initial Rep. Deep Sea, 71, 565-581, 1983.

Gombos Jr., A. M.: Paleogene and Neogene diatoms from the Falkland plateau and Malvinas outer basin: Leg 36, Deep Sea Drilling Project, in: Initial Rep. Deep Sea, edited by: Wise Jr., S. W., 36, 575-687, US Government Printing Office, Washington, D.C., 1977.

Gombos Jr., A. M.: Late Paleocene Diatoms in the Cape Basin, in: Initial Rep. Deep Sea, edited by: Bailey, M. G., 73, 495-511, US Government Printing Office, Washington, D.C., 1984.

Gradstein, F. M., Ogg, J. G., Schmitz, M. D., and Ogg, G. M.: The Geologic Time Scale, Elsevier, Amsterdam, 2012.

Greville, R. K.: Descriptions of New and Rare Diatoms. Series IX., J. Microsc.-Oxford, 11, 63-76, 1863.

Greville, R. K.: Descriptions of New and Rare Diatoms. Series XIII., J. Microsc.-Oxford, 12, 87-94, 1864.

Greville, R. K.: Descriptions of New and Rare Diatoms. Series XVI., J. Microsc.-Oxford, 13, 43-84, 1865.

Grove, E. and Sturt, G.: On a Fossil Marine Diatomaceous Deposit from Oamaru, Otago, New Zealand: Part II, Journal of the Quekett Microscopical Club, 2, 7-12, 1886a.

Grove, E. and Sturt, G.: On a Fossil Marine Diatomaceous Deposit from Oamaru, Otago, New Zealand: Appendix, Journal of the Quekett Microscopical Club, 2, 134-148, 1886b.

Grunow, A.: Die Diatomeen von Franz Josefs-Land, KaiserlichKöniglichen Hof-und Staatsdruckerei Wien, 1884.

Hajós, M.: Upper Eocene and lower Oligocene Diatomaceae, Archaeomonadaceae, and Silicoflagellatae in southwestern Pacific sediments, DSDP leg 29, Initial Rep. Deep Sea, 29, 817-883, 1976.
Hajós, M. and Stradner, H.: Late Cretaceous Archaeomonadaceae, Diatomaceae, and Silicoflagellatae from the South Pacific Ocean, Deep Sea Drilling Project, Leg 29, Site 275, Initial Reports of the Deep Sea Drilling Project, 29, 913-1009, 1975.

Hanna, G. D.: Cretaceous diatoms from California, Occasional papers of the California Academy of Sciences, 13, 1927.

Harwood, D., Chang, K., and Nikolaev, V.: Late Jurassic to earliest Cretaceous diatoms from Jasong Synthem, Southern Korea: Evidence for a terrestrial origin, in: Abstracts, 18th International Diatom Symposium, Miedzyzdroje, Poland, p. 81, Szczecin University Press Szczecin, Poland, 2004.

Harwood, D. M.: Upper Cretaceous and lower Paleocene diatom and silicoflagellate biostratigraphy of Seymour Island, eastern Antarctic Peninsula, Geol. Soc. Am. Mem., 169, 55-130, 1988.

Harwood, D. M. and Nikolaev, V. A.: Cretaceous diatoms: morphology, taxonomy, biostratigraphy, Short courses in paleontology, 8 , 81-106, 1995.

Harwood, D. M., Nikolaev, V. A., and Winter, D. M.: Cretaceous records of diatom evolution, radiation, and expansion, in: Pond scum to carbon sink; geological and environmental applications of the diatoms, edited by: Staratt, S. W., The Paleontological Society Papers, 13, 33-59, Paleontological Society, 2007.

Heiberg, P. A. C.: Kritisk oversigt over de danske diatomeer, W. Prior, 1863.

Hollis, C.: Latest Cretaceous to Late Paleocene Radiolaria from Marlborough (New Zealand) and DSDP Site 208, PhD thesis, University of Auckland, 1991.

Hollis, C.: Latest Cretaceous to Late Paleocene radiolarian biostratigraphy: A new zonation from the New Zealand region, Mar. Micropaleontol., 21, 295-327, 1993.

Hollis, C.: Radiolarian faunal change through the CretaceousTertiary transition of eastern Marlborough, New Zealand, in: Cretaceous-Tertiary Mass Extinctions: Biotic and Environmental Changes, edited by: MacLeod, N., 173-204, 1996.

Hollis, C.: Cretaceous-Paleocene Radiolaria from eastern Marlborough, New Zealand, vol. 17 of Institute of Geological \& Nuclear Sciences monograph, Institute of Geological \& Nuclear Sciences, 1997.

Hollis, C., Rodgers, K., and Parker, R.: Siliceous plankton bloom in the earliest Tertiary of Marlborough, New Zealand, Geology, 23, 835-838, 1995.

Hollis, C., Rodgers, K., Strong, C., Field, B., and Rogers, K.: Paleoenvironmental changes across the Cretaceous/Tertiary boundary in the northern Clarence Valley, southeastern Marlborough, New Zealand, New Zeal. J. Geol. Geop., 46, 209-234, 2003 a.

Hollis, C., Strong, C., Rodgers, K., and Rogers, K.: Paleoenvironmental changes across the Cretaceous/Tertiary boundary at Flaxbourne River and Woodside Creek, eastern Marlborough, New Zealand, New Zeal. J. Geol. Geop., 46, 177-197, 2003b.

Hollis, C. J., Stickley, C. E., Bijl, P. K., Schiøler, P., Clowes, C. D., Li, X., and Campbell, H.: The age of the Takatika Grit, Chatham Islands, New Zealand, Alcheringa, 41, 383-396, 2017.

Homann, M.: Die Diatomeen der Fur-Formation (Alttertiär) aus dem Limfjord-Gebiet, Nordjütland/Dänemark, Geologisches Jahrbuch Reihe A, 123, 1991.

Hustedt, F.: Die Kieselalgen Deutschlands, Österreichs und der Schweiz mit Berücksichtigung der übrigen Länder Europas sowie der angrenzenden Meeresgebiete. Part I, vol. 7 
of Kryptogamen-Flora von Deutschland, Österreich und der Schweiz, Akademische Verlagsgesellschaft, 1930.

Jousé, A. P.: Novye diatomovye I kremnevye zhgutikovye vodorosli verkhnemelovogo vozrasta iz glinistykh peskov basseina reki Bol'shoi Aktai (vostochnyi sklon Severnogo Urala), Botaničeskie materialy Otdela Sporovych Rastenij, 6, 65-78, 1949.

Jousé, A. P.: Diatomeae aetatis palaeocaeni Uralii Septentrionalis, Notulae systematicae e sectione cryptogamica Instituti Botanici nomine VI Komarovii Academiae Scientiarum URSS, 7, 24-42, 1951.

Jousé, A. P.: Species novae diatomacearum aetatis paleogenae, Botaničeskie materialy Otdela Sporovych Rastenij, 10, 81-103, 1955.

Katz, M. E., Finkel, Z. V., Grzebyk, D., Knoll, A. H., and Falkowski, P. G.: Evolutionary trajectories and biogeochemical impacts of marine eukaryotic phytoplankton, Annu. Rev. Ecol. Evol. S., 523-556, 2004.

Koizumi, I.: Diatom biostratigraphy of the Japan Sea; Leg 127, Proceedings of the Ocean Drilling Program, Scientific Results, 127, 249-289, 1992.

Krotov, A. and Schibkova, K.: Species novae diatomacearum e paleogeno montium uralensium, Botan. Mater. Otd. Sporovykh Rast., Botan. Inst., Akad. Nauk SSSR, 12, 112-129, 1959.

Lazarus, D.: Age depth plot and age maker: Age modelling of stratigraphic sections on the Macintosh series of computers, Geobyte, 2, 7-13, 1992.

Lazarus, D.: Neptune: a Mar. Micropaleontol. database, Math. Geol., 26, 817-832, 1994.

Lazarus, D.: The Micropaleontological Reference Centers Network, Sci. Dril., 3, 46-49, https://doi.org/10.2204/iodp.sd.3.10.2006, 2006.

Lazarus, D.: The deep-sea microfossil record of macroevolutionary change in plankton and its study, Geol. Soc. London Spec. Publ., 358, 141-166, 2011.

Lazarus, D., Barron, J., Renaudie, J., Diver, P., and Türke, A.: Cenozoic Planktonic Marine Diatom Diversity and Correlation to Climate Change, PLoS ONE, 9, e84857, https://doi.org/10.1371/journal.pone.0084857, 2014.

Long, J. A., Fuge, D. P., and Smith, J.: Diatoms of the Moreno shale, J. Paleontol., 20, 89-118, 1946.

MacLeod, N., Rawson, P. F., Forey, P. L., Banner, F. T., BoudagherFadel, M. K., Bown, P. R., Burnett, J. A., Chambers, P., Culver, S., Evans, S. E., Jeffery, C., Kaminski, M. A., Lord, A. R., Milner, A. C., Milner, A. R., Morris, N., Owen, E., Rosen, B. R., Smith, A. B., Taylor, P. D., Urquhart, E., and Young, J. R.: The Cretaceous-tertiary biotic transition, J. Geol. Soc. London, 154, 265-292, 1997.

Medlin, L. K.: Why silica or better yet why not silica? Speculations as to why the diatoms utilise silica as their cell wall material, Diatom Res., 17, 453-459, 2002.

Medlin, L. K.: A timescale for diatom evolution based on four molecular markers: reassessment of ghost lineages and major steps defining diatom evolution., Vie Milieu, 65, 219-238, 2015.

Medlin, L. K.: Evolution of the diatoms: major steps in their evolution and a review of the supporting molecular and morphological evidence, Phycologia, 55, 79-103, 2016.
Mukhina, V. V.: Species composition of the late Paleocene diatoms and silicoflagellates in the Indian Ocean, Micropaleontology, 22, 151-158, 1976.

Muttoni, G. and Kent, D. V.: Widespread formation of cherts during the early Eocene climate optimum, Palaeogeogr. Palaeocl., 253, 348-362, 2007.

National Geophysical Data Center: Core Data from the Deep Sea Drilling Project Legs 1-96. World Data Center for Marine Geology \& Geophysics, Seafloor Series, 1, http://www.ngdc.noaa. gov/mgg/fliers/00mgg03.html (last access: 8 May 2013), 2000.

National Geophysical Data Center: Core Data from the Ocean Drilling Program Legs 101-129. World Data Center for Marine Geology \& Geophysics, Seafloor Series, 2, http://www. ngdc.noaa.gov/mgg/geology/odp/start.htm (last access: 23 April 2013), 2001.

Nikolaev, V. A. and Harwood, D. M.: Morphology and taxonomic position of the Late Cretaceous diatom genus Pomphodiscus Barker \& Meakin, Micropaleontology, 46, 167-177, 2000.

Nikolaev, V. A. and Harwood, D. M.: Diversity and classification of centric diatoms, in: Proceedings of the 16th International Diatom Symposium, edited by: Economou-Amilli, A., 127-152, University of Athens, 2002.

Nikolaev, V. A., Kociolek, J. P., Fourtanier, E., Barron, J. A., and Harwood, D. M.: Late Cretaceous diatoms (Bacillariophyceae) from the Marca shale member of the Moreno formation, California, Occasional papers of the California Academy of Sciences, 152, 1-119, 2001.

Oreshkina, T. and Aleksandrova, G.: Terminal Paleocene of the Volga middle reaches: Biostratigraphy and paleosettings, Stratigr. Geo. Correl.+, 15, 206-230, 2007.

Oreshkina, T. V.: Evidence of late Paleocene-early Eocene hyperthermal events in biosiliceous sediments of Western Siberia and adjacent areas, Austrian J. Earth Sc., 105, 145-153, 2012.

Oreshkina, T. V. and Oberhaensli, H.: Diatom turnover in the early Paleogene diatomite of the Sengiley section, middle Povolzhie, Russia: A response to the initial Eocene thermal maximum?, in: Causes and consequences of globally warm climates in the early Paleogene, edited by: Wing, S. L., Gingerich, P. D., Schmitz, B., and Thomas, E., 169-179, Geological Society of America, Boulder, Colorado, 2003.

Oreshkina, T. V. and Radionova, E. P.: Diatom record of the Paleocene-Eocene Thermal Maximum in marine paleobasins of Central Russia, Transuralia and adjacent regions, Nova Hedwigia, Beiheft, 143, 307-336, 2014.

Pantocsek, J.: Beiträge zur Kenntniss der fossilen Bacillarien Ungarns, II Theil: Brackwasser Bacillarien, 1889.

Petrizzo, M. R.: An early late Paleocene event on Shatsky Rise, northwest Pacific Ocean (ODP Leg 198): evidence from planktonic foraminiferal assemblages, in: Proceedings of the Ocean Drilling Program, Scientific Results, edited by: Bralower, T. J., Premoli-Silva, L., and Malone, M. J., 198, 1-29, Ocean Drilling Program, College Station, TX, 2005.

Rabosky, D. L. and Sorhannus, U.: Diversity dynamics of marine planktonic diatoms across the Cenozoic, Nature, 457, 183-186, 2009.

Radionova, E., Beniamovski, V. N., Iakovleva, A., Muzylov, N., Oreshkina, T. V., Shcherbinina, E. A., and Kozlova, G.: Early Paleogene transgressions: Stratigraphical and sedimentological 
evidence from the northern Peri-Tethys, Geological Society of America Special Papers, 239-262, 2003.

Renaudie, J.: Quantifying the Cenozoic marine diatom deposition history: links to the $\mathrm{C}$ and Si cycles, Biogeosciences, 13, 60036014, https://doi.org/10.5194/bg-13-6003-2016, 2016.

Renaudie, J. and Diver, P.: nsb_adp_wx, version 0.6.1, available at: https://github.com/plannapus/nsb_adp_wx/releases, last access: 1 December 2017.

Ross, R.: Some Eocene diatoms from South Atlantic cores. II. Rutilaria Greville, Occasional Papers of the Californian Academy of Science, 1976.

Ross, R.: Revision of Rutilaria Greville (Bacillariophyta), Bulletin of the Natural History Museum, Botany series, 25, 1-93, 1995.

Ross, R. and Sims, P. A.: Syringidium Ehrenb., Dextradonator Ross \& Sims, nov. gen. and Abas Ross \& Sims, nov. gen., Bacillaria, 3, 115-127, 1980.

Ross, R. and Sims, P. A.: Some genera of the Biddulphiaceae (diatoms) with interlocking linking spines, Bulletin of the British Museum (Natural History), Botany Series, 13, 277-381, 1985.

Ross, R. and Sims, P. A.: Further genera of the Biddulphiaceae (diatoms) with interlocking linking spines, Bulletin of the British Museum (Natural History), Botany Series, 16, 269-311, 1987.

Ross, R. and Sims, P. A.: A revision of Actinodiscus Greville, Craspedoporus Greville and related genera (Eupodiscaceae), Diatom Res., 15, 285-347, 2000.

Scheschukova-Poretzkaja, V. and Gleser, S.: Novie vidy morskikh paleogenovikh diatomovikh vodoroslei U.S.S.R. (Diatomeae Marinae novae e Paleogeno Ucrainiae), Novitates Systematicae Plantarum Non Vascularium (Academia Scientiarum URSS Institutum Botanicum Nomine V.L. Komarovii), 78-92, 1964.

Schmidt, A.: Atlas der Diatomaceen-Kunde, R. Reisland, Leipzig, 1887.

Schrader, H. J. and Fenner, J.: Norwegian Sea Cenozoic diatom biostratigraphy and taxonomy; Part I, Norwegian Sea Cenozoic diatom biostratigraphy, Initial Rep. Deep Sea, 38, 921-962, 1976.

Schulz, P.: Diatomeen aus senonen Schwammgesteinen der Danziger Bucht, Zugleich ein Beitrag zur Entwicklungsgeschichte der Diatomeen, Botanisches Archiv, 37, 383-413, 1935.

Shipboard Scientific Party: Site 208, in: Initial Reports of the Deep Sea Drilling Project, edited by: Burns, R. E., Andrews, J. E., van der Lingen, G. J., Churkin Jr., M., Galehouse, J. S., Packham, G. H., Davies, T. A., Kennett, J. P., Dumitrica, P., Edwards, A. R., and Von Herzen, R. P., 271-331, Texas A \& M University, College Station, TX, 1973.

Shipboard Scientific Party: Site 384: The Cretaceous/Tertiary boundary, Aptian reefs, and the J-anomaly Ridge, in: Initial Reports of the Deep Sea Drilling Project, edited by: Tucholke, B. E., Vogt, P. R., Murdmaa, I. O., Rothe, P., Houghton, R. L., Galehouse, J. S., Kaneps, A., McNulty Jr., C. L., Okada, H., Kendrick, J. W., Demars, K. R., and McCave, I. N., 43, 107, Texas A \& M University, College Station, TX, 1979.

Shipboard Scientific Party: Site 752, in: Proceedings of the Ocean Drilling Program, Initial Results, edited by: Peirce, J. W., Weissel, J. K., Taylor, E., Dehn, J., Driscoll, N. W., Farrell, J. W., Fourtanier, E., Frey, F. A., Gamson, P. D., Gee, J. S., Gibson, I. L., Janecek, T. R., Klootwijk, C. T., Lawrence, J. R., Littke, R., Newman, J. S., Nomura, R., Owen, R. M., Pospichal, J. J.,
Rea, D. K., Resiwati, P., Saunders, A. D., Smit, J., Smith, G. M., Tamaki, K., Weis, D., Wilkinson, C., Haskins Dearmont, L., Kapitan Mazzullo, E., and Stewart, N. J., 121, 111-169, Ocean Drilling Program, College Station, TX, 1989.

Sims, P. A.: Skeletonemopsis, a new genus based on the fossil species of the genus Skeletonema Grev., Diatom Res., 9, 387410, 1994a.

Sims, P. A.: Benetorus, Gladiopsis and related genera from the Cretaceous, Diatom Res., 9, 165-187, 1994b.

Sims, P. A.: The early history of the Biddulphiales. I. The genus Medlinia gen. nov., Diatom Res., 13, 337-374, 1998.

Sims, P. A.: The early history of the Biddulphiales II. The genus Euodiella gen. nov., Diatom Res., 15, 383-407, 2000.

Sims, P. A. and Crawford, R. M.: The morphology and taxonomy of the marine centric diatom genus Paralia. II. Paralia crenulata, P. fausta and the new species, P. hendeyi, Diatom Res., 17, 363382, 2002.

Sims, P. A. and Ross, R.: Some Cretaceous and Palaeogene Trinacria (diatom) species, Bulletin of the British Museum (Natural History), Botany Series, 18, 275-322, 1988.

Smetacek, V.: Diatoms and the Ocean Carbon Cycle, Protist, 150, 25-32, 1999.

Sorhannus, U.: A nuclear-encoded small-subunit ribosomal RNA timescale for diatom evolution, Mar. Micropaleontol., 65, 1-12, 2007.

Strelnikova, N.: De diatomis Cretae superioris raris et novis declivis orientalis montium Uralensium polarium., Novosti Sistematiki Nizshikh Rastenii, 2, 29-37, 1965.

Suto, I., Jordan, R. W., and Watanabe, M.: Taxonomy of the fossil marine diatom resting spore genus Goniothecium Ehrenberg and its allied species, Diatom Res., 23, 445-469, 2008.

Tapia, P. M. and Harwood, D. M.: Upper Cretaceous diatom biostratigraphy of the Arctic archipelago and northern continental margin, Canada, Micropaleontology, 48, 303-342, 2002.

Tréguer, P., Nelson, D. M., Van Bennekom, A. J., DeMaster, D. J., Leynaert, A., and Quéguiner, B.: The silica balance in the world ocean: a reestimate, Science, 268, 375-379, 1995.

van Heurck, H. F.: Synopsis des Diatomées de Belgique, H. van Heurck, Anvers, 1882.

Wiese, R., Renaudie, J., and Lazarus, D. B.: Testing the accuracy of genus-level data to predict species diversity in Cenozoic marine diatoms, Geology, 44, 12, 2016.

Williams, D. M.: Illustrated catalogue of the type specimens in the Greville diatom herbarium, Bulletin of the British Museum (Natural History), Botany Series, 18, 1-148, 1988.

Witkowski, J., Harwood, D. M., and Chin, K.: Taxonomic composition, paleoecology and biostratigraphy of late Cretaceous diatoms from Devon Island, Nunavut, Canadian High Arctic, Cretaceous Res., 32, 277-300, 2011.

Witkowski, J., Sims, P. A., Strelnikova, N. I., and Williams, D. M.: Entogoniopsis gen. nov. and Trilamina gen. nov.(Bacillariophyta): a survey of multipolar pseudocellate diatoms with internal costae, including comments on the genus Sheshukovia Gleser, Phytotaxa, 209, 1-89, 2015.

Witt, O.: Ueber den Polierschiefer von Archangelsk-Kurojedowo im Gouv. Simbirsk., Verhandlungen der Russisch-kaiserlichen mineralogischen Gesellschaft zu St. Petersburg. Series II, 1885.

Wright, N., Zahirovic, S., Müller, R. D., and Seton, M.: Towards community-driven paleogeographic reconstructions: 
integrating open-access paleogeographic and paleobiology data with plate tectonics, Biogeosciences, 10, 1529-1541, https://doi.org/10.5194/bg-10-1529-2013, 2013.

Zachos, J. C., Dickens, G. R., and Zeebe, R. E.: An early Cenozoic perspective on greenhouse warming and carbon-cycle dynamics, Nature, 451, 279-283, 2008.
Zalat, A. A.: Cretaceous diatoms biostratigraphy and taxonomy from the North-eastern Sinai, Egypt, Micropaleontology, 59, 305-323, 2013. 